\title{
India: Defining and Explaining Inclusive Growth and Poverty Reduction
}




\section{India: Defining and Explaining Inclusive Growth and Poverty Reduction}

Rahul Anand, Volodymyr Tulin, and Naresh Kumar 


\title{
IMF Working Paper
}

Asia and Pacific Department

\author{
India: Defining and Explaining Inclusive Growth and Poverty Reduction ${ }^{1}$ \\ Prepared by Rahul Anand, Volodymyr Tulin, and Naresh Kumar \\ Authorized for distribution by Paul Cashin
}

April 2014

\section{This Working Paper should not be reported as representing the views of the IMF. The views expressed in this Working Paper are those of the author(s) and do not necessarily represent those of the IMF or IMF policy. Working Papers describe research in progress by the author(s) and are published to elicit comments and to further debate.}

\begin{abstract}
We document the evolution of poverty and inequality across Indian states during the recent period of rapid growth (2004-09), and examine the role of growth and distribution in reducing poverty. Robust economic growth has been a major driver of poverty reduction and inclusiveness in India. We explore the role of economic policies and macrofinancial conditions in explaining inclusive growth and its components, using a new measure of inclusive growth. Social expenditures, spending on education, and educational attainment rates are important for fostering inclusive growth. Macro-financial stability, with particular attention to inflation risks, is also criticial for promoting inclusive growth.
\end{abstract}

JEL Classification Numbers: O12, O43, D31

Keywords: India, state level growth, poverty, inequality, inclusive growth

Authors’ E-Mail Addresses: ranand@imf.org; vtulin@imf.org; nkumar@imf.org

\footnotetext{
${ }^{1}$ We are grateful to Paul Cashin, Laura Papi and our colleagues in the Asia and Pacific Department for helpful comments and discussions. We benefited from the feedback received from the seminar participants at Ministry of Finance, Government of India, and the Reserve Bank of India. We thank Debra Loucks, May Inoue and Rosanne Heller for editorial assistance.
} 


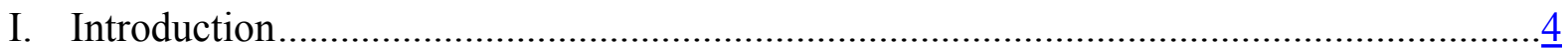

II. The Evolution of Poverty and Inequality ……….............................................................

A. Nationwide Income and Consumption Growth ........................................................... $\frac{6}{7}$

B. Variation in Growth Across States ......................................................................

C. Poverty Reduction and Inequality in the Context of High Growth ............................... 2

D. Analysis of Poverty Reduction and Inequality ...........................................................13

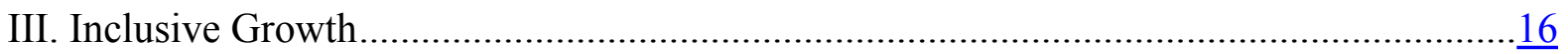

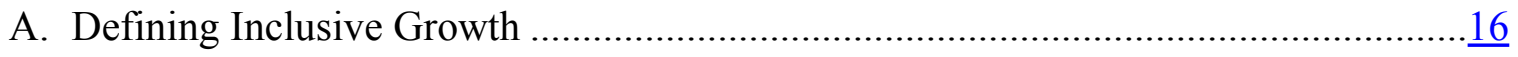

B. Evolution of Inclusiveness …………………………..........................................

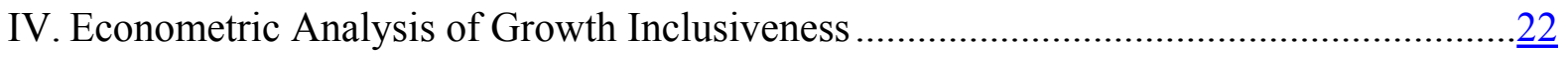

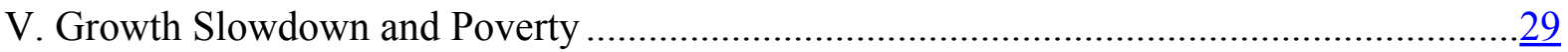

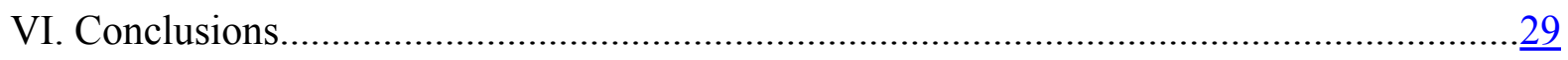

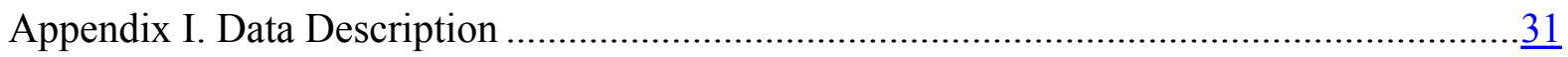

Figures

1. Ratio of Urban to Rural Real Consumption...................................................................

2. Growth in Real Net State Domestic Product per Capita....................................................

3. Regional Variation in Growth and Income Levels ........................................................

4. Regional Variation in Consumption ...........................................................................

5. Growth in Rural and Urban Consumption .................................................................

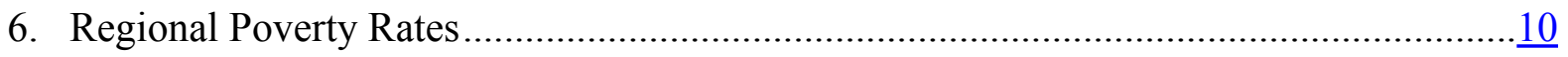

7. Regional Poverty Reduction Progress …………….................................................

8. Real NSDP Per Capita: Ratio of Richest to Poorest States ..............................................11

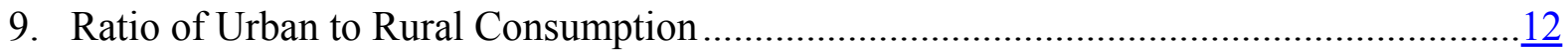

10. Gini Coefficient: Rural Households............................................................................

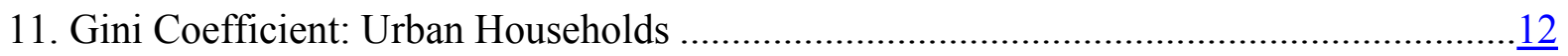

12. Comparison of Growth and Inequality Contribution to Poverty Reduction .......................13

13. Comparison of Growth and Inequality Contributions to Poverty Reduction Between

Rural and Urban Households ................................................................................

14. Expenditure Growth by Different Segments of Welfare Distribution: Rural and Urban Households............................................................................................

15. Comparison of Growth Incidence Curve between Rural and Urban Households ...............16

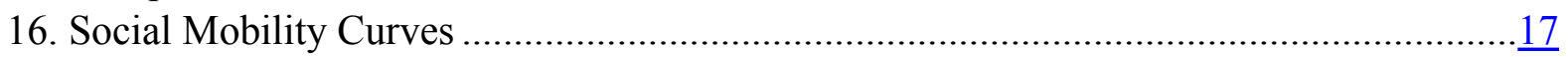

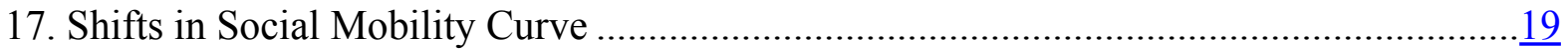


Tables

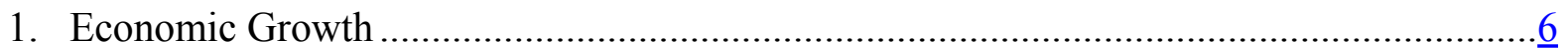

2. Evolution of Poverty .............................................................................................. $\underline{9}$

3. Average Decline in Poverty Headcount Rate by State, 16 Major States .........................11

4. Progress on Growth, Poverty Reduction and Inequality: Summary Table for

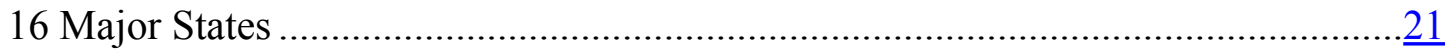

5. Regression Analysis of Growth Inclusiveness: State-Level, Urban and Rural

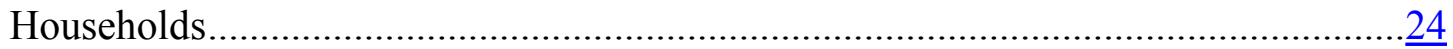

6. Regression Analysis of Poverty Reduction (Datt-Ravallion Decomposition):

State-Level, Urban and Rural Households.............................................................25

7. Regression Analysis of Growth Inclusiveness: Rural Households ................................27

8. Regression Analysis of Poverty Reduction (Datt-Ravallion Decomposition): Rural

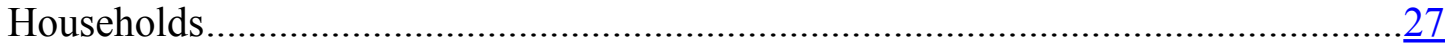

9. Regression Analysis of Growth Inclusiveness: Urban Households................................28

10. Regression Analysis of Poverty Reduction (Datt-Ravallion Decomposition): Urban

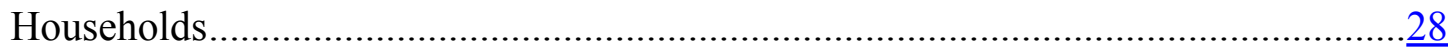

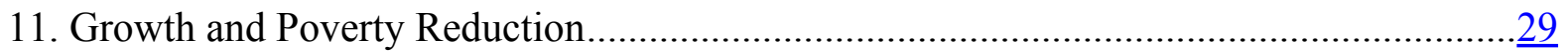

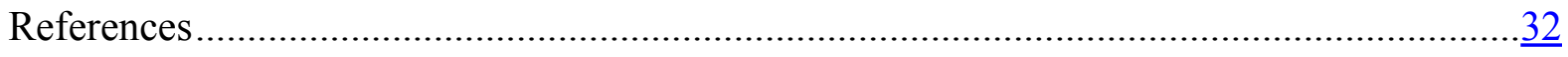




\section{INTRODUCTION}

India has grown strongly since the economic reforms of the early 1990s, with growth averaging around 7 percent during 1993/94-2009/10. After growing at an average rate of $61 / 4$ percent during 1993/94-2003/04, growth accelerated to 81/2 percent during 2004/05-2009/10. High rates of economic growth have been more broadly shared than ever before across the Indian states during this latter period - many poor states grew at double-digit rates. This rapid economic growth has contributed to a substantial reduction in poverty. The poverty headcount rate, measured using the national poverty line, declined by 1.5 percentage points per year in 2004/05-2009/10, double the rate of the preceding decade. More recent data suggests that between 2004/05-2011/12, poverty declined by 2.2 percentage points per year ${ }^{2}$, which is about three times the pace of the poverty reduction of the preceding decade. Yet India continues to have the largest number of poor (approximately 300 million) in the world, and nearly half of the poor are concentrated in five states.

The period of rapid growth and poverty reduction (2004-09) also witnessed a rise in inequality, with the Gini index rising from about 0.27 in rural and 0.35 in urban India in $2004 / 05$ to about 0.28 and 0.37 , respectively, in 2009/10. Moreover, rural-urban as well as regional inequality also increased during this period - the ratio of urban to rural per capita consumption and the ratio of real per capita income of the richest state to that of the poorest state both rose.

Aware of these widening disparities, the government declared achieving faster and more inclusive growth the stated objective of the Eleventh Five Year Plan (2007/08-2011/12). Inclusive growth continues to be the focal point of the Twelfth Five Year Plan. The stated vision of the recently-released draft Twelfth Plan document is "of India moving forward in a way that would ensure a broad-based improvement in living standards of all sections of the people through a growth process which is faster than in the past, more inclusive and also more environmentally sustainable."

Considering that poverty reduction and promoting inclusive growth are the two most important policy priorities of the government, this paper aims at analyzing the evolution of poverty, inequality, and inclusive growth in India during 2004-09. In order to examine the role of various macroeconomic policies in poverty reduction and inclusiveness, we also look at the explanatory factors of inclusive growth and poverty reduction.

The 2009/10 round of the household consumption expenditure survey by the National Sample Survey (NSS), which uses the same methodology as earlier NSS rounds (namely

\footnotetext{
${ }^{2}$ Slower progress in poverty reduction during 2004/05-2009/10 may reflect the fact that 2009/10 was a severe drought year (Planning Commission of India, 2013).
} 
1993/94 and 2004/05), provides us an opportunity to focus on poverty, inequality and inclusive growth during the recent 2004/05-2009/10 growth episode.

While documenting the evolution of poverty and inequality, we draw upon a rich literature looking at these issues in India (Datt and Ravallion, 1996; Datt and Ravallion, 2002a and 2002b; Purfield, 2006; and Topalova, 2008 among others). We exploit the methodology of Datt and Ravallion (1992) in examining the role of growth and equity in poverty reduction. For growth to be sustainable and effective in reducing poverty, it needs to be inclusive (Berg and Ostry, 2011; and Kraay, 2004). Therefore, to study inclusive growth, we use a measure of inclusive growth proposed by Anand and others (2013). This is a unified measure of inclusive growth, which integrates growth and income distribution into a single measure.

To better understand the determinants of growth inclusiveness, we examine the links between Indian state-level socio-economic indicators and inclusive growth and poverty reduction outcomes over the period of 1993/94 to 2009/10. We also explore the links between these socio-economic indicators and the components (growth and distribution) of inclusive growth and poverty reduction. Our results suggest that economic growth has been a major driver of poverty reduction and inclusiveness in India. While positive distributional changes aided poverty reduction in rural areas, the worsening of distribution hampered poverty reduction in urban areas. Government expenditures, particularly social expenditure, are closely linked to inclusive growth and poverty reduction. Our analysis also suggests that states that boosted spending on education and those that boosted fundamental educational attainment rates experienced better inclusive growth outcomes. This is because spending on educationwhich is a component of spending on social needs - not only fosters growth but, through better jobs and higher incomes, advances equity (by helping the poor more). In addition, we find that sustaining robust and inclusive growth will require maintaining macrofinancial stability, with particular attention to inflation risks. Considering that growth is a major driver of poverty reduction, our results suggest that the current growth slowdown in India, if protracted, could severely hamper poverty reduction and inclusiveness.

The paper is organized as follows. In the next section, we examine the evolution of growth, poverty and inequality in India at the national and state level. We also decompose poverty reduction into its growth and distributional components. In Section III, we document the evolution of inclusive growth, and Section IV examines the determinants of inclusive growth. Section V looks at the implication of the recent growth slowdown on poverty reduction. Section VI concludes. 


\section{The Evolution of Poverty ANd IneQuality}

\section{A. Nationwide Income and Consumption Growth}

India's annual growth accelerated to about $8 \frac{1}{2}$ percent on average during 2004-09 from an average of $6 \frac{1}{4}$ percent during 1993/94-2004/05. Also, the annual growth rate of real GDP per capita accelerated to an average of $6 \frac{1}{2}$ percent during 2004/05-2009/10 from 4 $1 / 2$ percent in 1993/94-2004/05. A similar pattern is also observed in the national accounts-based growth of real per capita consumption. Household survey data, however, suggest a somewhat slower growth in per capita consumption (Table 1). According to the household survey data, during 1993/94 to 2004/05, the average rate of annual growth in per capita consumption expenditure was only half as large as the rate measured in the National Accounts Statistics (NAS). It further shrank to nearly 44 percent of the NAS growth rate during 2004/052009/10. Much slower consumption growth based on the survey data points to a systematic underestimation of consumption of all respondents (Bhalla, 2003), or a disproportionately large increase in the income of very rich, who are much less likely to be picked up in expenditure surveys (Banerjee and Piketty, 2005). The gap between the two measures has increased over time. ${ }^{4}$

\begin{tabular}{lccccc} 
Table 1. India: Economic Growth & (Average annual percent change, per capita) \\
\hline \hline & GDP & $\begin{array}{c}\text { Private } \\
\text { Consumption } \\
\text { (NAS) }\end{array}$ & $\begin{array}{c}\text { Private } \\
\text { Consumption } \\
\text { (NSS) }\end{array}$ & $\begin{array}{c}\text { Private } \\
\text { Consumption: Rural } \\
\text { (NSS) }\end{array}$ & $\begin{array}{c}\text { Private } \\
\text { Consumption: Urban } \\
\text { (NSS) }\end{array}$ \\
\hline $1993 / 94-2004 / 05$ & 4.5 & 3.1 & 1.7 & 1.8 & 1.8 \\
$2004 / 05-2009 / 10$ & 6.8 & 5.9 & 2.6 & 1.8 & 3.0 \\
\hline
\end{tabular}

Source: IMF staff calculations.

Notes: NAS denotes Natioanal Accounts Statistics basis, NSS denotes National Sample Survey basis.

Rural and urban areas differed markedly in the growth of private consumption. While average growth in private consumption remained nearly the same in the rural areas compared with the average growth over the preceding ten years, growth in urban private consumption accelerated during 2004-09, widening the gap between urban and rural consumption. The ratio of urban to rural average real per capita consumption rose by over 6 percent between 2004/05 and 2009/10 (Figure 1). Relatively

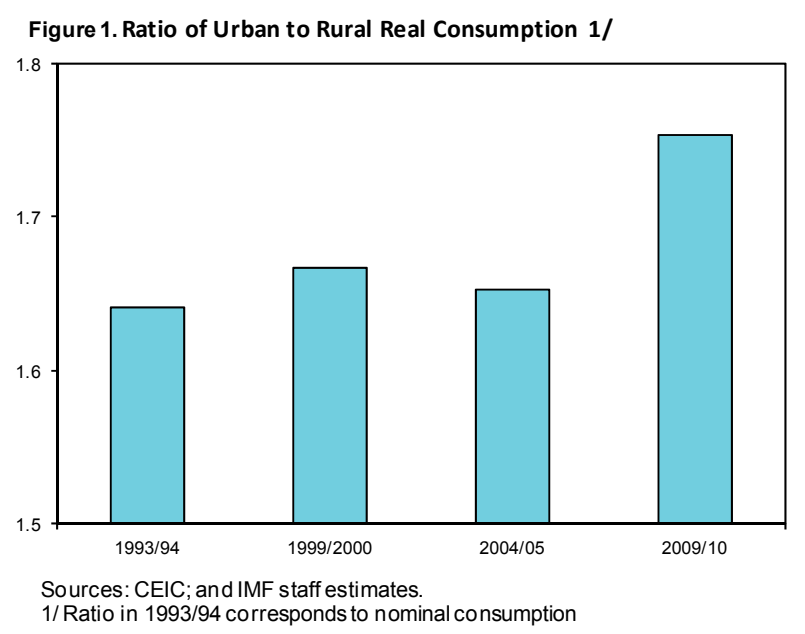

\footnotetext{
${ }^{3}$ These periods have been chosen based on the availability of household survey data and to capture the changes in the Indian economy following the reforms of the 1990s.

${ }^{4}$ For discussion on the increasing gap between household consumption data and the NAS data, please refer to Topalova, 2008.
} 
higher rural inflation, which resulted in the deterioration of rural households' purchasing power, accounts for nearly half of the differential in average real consumption growth between urban and rural households.

\section{B. Variation in Growth Across States}

To look at regional (state-wise) variation in economic growth we focus on 16 major states, which account for over 90 percent of India's population and close to 90 percent of its domestic product. ${ }^{5}$ These states comprise Andhra Pradesh, Assam, Bihar, Gujarat, Haryana, Himachal Pradesh, Karnataka, Kerala, Madhya Pradesh, Maharashtra, Orissa, Punjab, Rajasthan, Tamil Nadu, Uttar Pradesh and West Bengal.

These states vary considerably in real per capita income- they varied from Rs.11,000 to Rs. 57,500 in 2009/10. Despite this variation in per capita income, growth acceleration during 2004/05-2009/10 was shared by all states. Even though growth varied across states, all states in the sample witnessed higher average growth during 2004/05-2009/10 compared to $1993 / 94-2004 / 05$ period (Figure 2). For example, the average growth rates in Bihar and Uttar Pradesh (two states with low per capita income) almost tripled. Assam, Madhya Pradesh, Maharashtra, Punjab, and Tamil Nadu grew two times faster during 2004-2009. However, growth rates in Himachal Pradesh and West Bengal remained similar to those witnessed during 1993/94-2004/05.

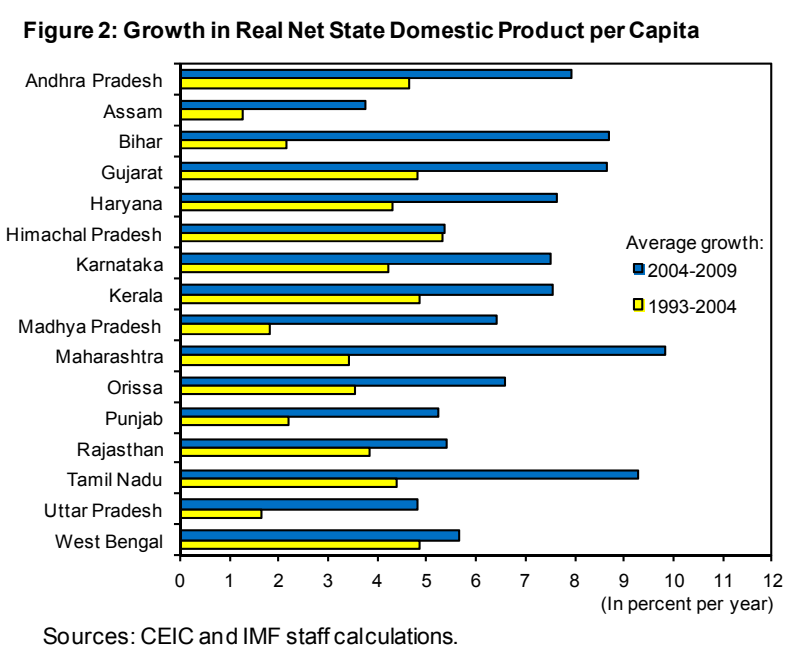

Sources: CEIC and IMF staff calculations.

Compared with 1993/94-2004/05, the degree of dispersion in growth rates across states decreased during 2004/05-2009/10. The coefficient of variation of growth rates decreased from 0.35 in the first period to 0.28 in the second. The range of variation in the first period varied from a low of 1.4 percent per year for Assam to a high of 5.2 percent per year for Kerala, a ratio of 3.9 between the highest and the lowest. In the second period, the range increased from a low of 3.4 percent per year for Assam to a high of 9.6 percent for Tamil $\mathrm{Nadu}$, decreasing the ratio to 2.8 .

\footnotetext{
${ }^{5}$ Excluding Jammu and Kashmir, the Northeastern states, and the union territories. The 16 states accounted for 90.3 percent of India's total population as per the 2011 Census.
} 
During 2004/05-2009/10, all high- and middle-income states except Himachal Pradesh and Punjab grew faster than the national average (Figure 3). Amongst the poorer states, Bihar witnessed a relatively high growth of per capita state domestic product during 2004/052009/10. However, most of the poor states (Assam, Rajasthan, and Uttar Pradesh) grew much slower than the national average (growth in these states was also slower than the national average during 1993/94-2004/05).

Consumption patterns across states reveal that faster-growing states generally experienced stronger private consumption growth (Figure 4). Similarly, states with relatively low levels of real consumption in 2004/05 experienced slower consumption growth. Moreover, some poorer states such as Assam and Bihar barely experienced any real consumption growth during 2004/05-2009/10. At the same time, richer states such as Himachal Pradesh, Kerala, and Maharashtra experienced strong income as well as consumption growth.
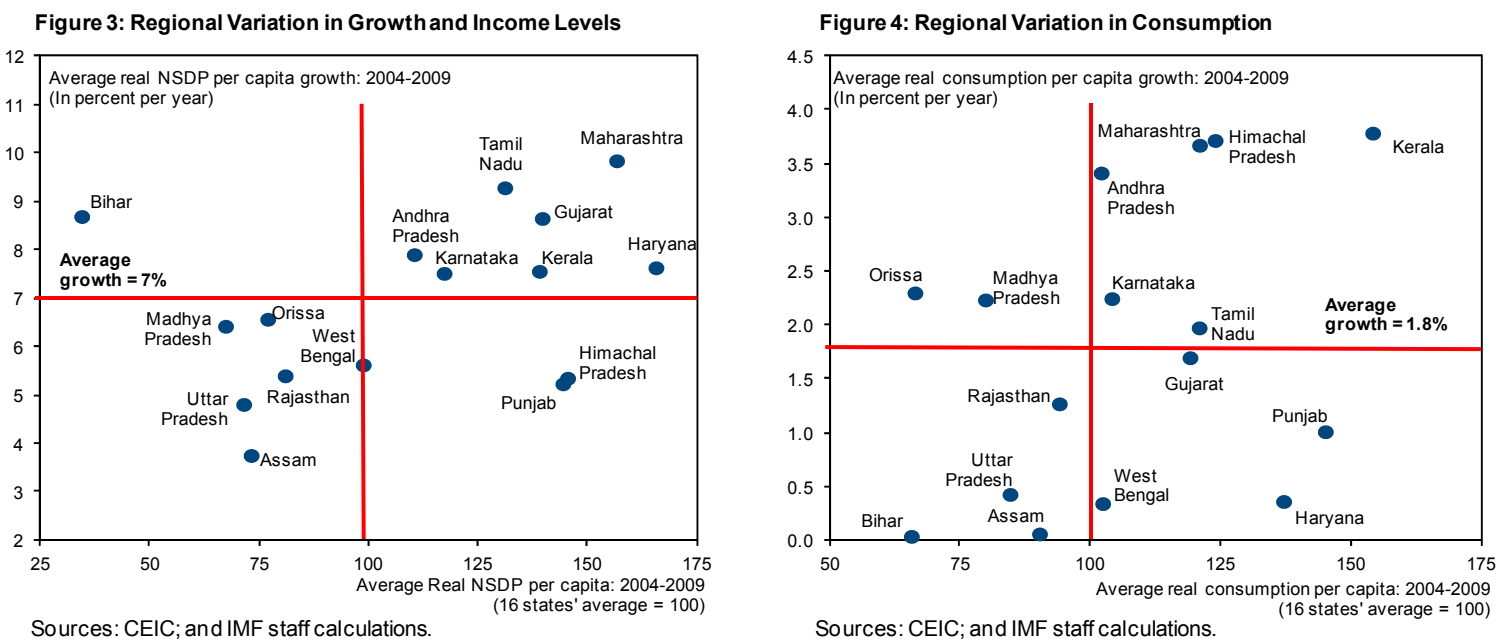

In 12 out of the 16 states, urban consumption growth was higher than rural consumption growth (Figure 5). Urban growth outpaced rural growth in the richest states, namely Himachal Pradesh, Kerala, and Tamil Nadu. Although rural growth outpaced urban growth in a relatively poor state of Bihar, both urban and rural growth were disappointingly low - with urban consumption appearing to have declined, to some extent a reflection of the drought year effect in 2009/10 NSSO survey data. Nationwide, urban consumption grew faster than rural consumption by about $1 \frac{1 / 4}{4}$ percentage points per year during 2004/05-2009/10.

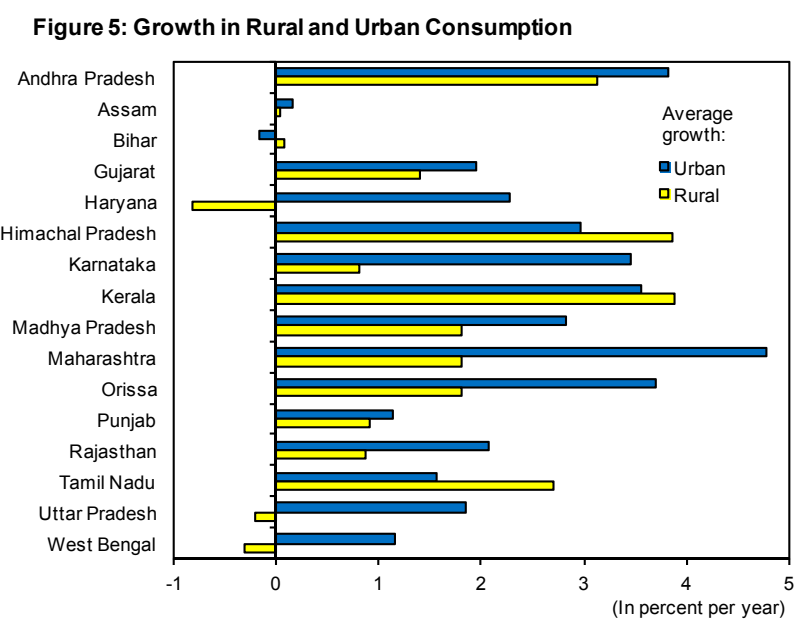

Sources: IMF staff calculations. 


\section{Poverty Reduction and Inequality in the Context of High Growth}

High growth during 2004/05-2009/10 enabled accelerated poverty reduction. Compared with the previous decade, the rate of poverty reduction doubled, with the share of the population living below the poverty line falling from 37.2 percent in $2004 / 05$ to 29.8 percent in $2009 / 10{ }^{6}$ The number of poor declined from 407 million in 2004/05 to 356 million in $2009 / 10$, in sharp contrast to the marginal increase in the number of poor during 1993/94$2004 / 05$ (Table 2). ${ }^{7}$ Based on the NSS $68^{\text {th }}$ round $^{8}$, the number of poor declined further to about 269 million in $2011 / 12$, with a corresponding reduction in the poverty headcount ratio to 21.9 percent.

Even though poverty declined sharply in both rural and urban areas, the average annual rate of poverty reduction during 2004/05-2009/10 was $1 / 2$ of one percentage point higher in rural areas. Furthermore, 2011/12 data suggest continued progress on poverty reduction in India, in particular in rural areas. Also, in terms of the number of poor, on average nearly 10 million rural poor crossed the poverty line annually as compared to 0.25 million people during 1993/94-2004/05. However, if the period of 2004/05-2011/12 is considered, nearly 15 million poor crossed the poverty line per year.

\begin{tabular}{|c|c|c|c|c|c|c|c|c|}
\hline & & \multirow[b]{2}{*}{$1993 / 94$} & \multirow[b]{2}{*}{$2004 / 05$} & \multirow[b]{2}{*}{$2009 / 10$} & \multirow[b]{2}{*}{$2011 / 12$} & \multicolumn{3}{|c|}{ Annual Average Decline in Poverty } \\
\hline & & & & & & $1993 / 94-2004 / 05$ & $2004 / 05-2009 / 10$ & $2004 / 05-2011 / 12$ \\
\hline \multirow{3}{*}{$\begin{array}{l}\text { Poverty Headcount Ratio } \\
\text { In percent }\end{array}$} & Rural & 50.1 & 41.8 & 33.8 & 25.7 & 0.8 & 1.6 & 2.3 \\
\hline & Urban & 31.8 & 25.7 & 20.9 & 13.7 & 0.6 & 1.0 & 1.7 \\
\hline & Total & 45.3 & 37.2 & 29.8 & 21.9 & 0.7 & 1.5 & 2.2 \\
\hline \multirow{3}{*}{$\begin{array}{l}\text { Number of Poor } \\
\text { In millions }\end{array}$} & Rural & 328.6 & 325.8 & 278.2 & 216.5 & 0.3 & 9.5 & 15.6 \\
\hline & Urban & 74.5 & 81.4 & 76.5 & 52.8 & -0.6 & 1.0 & 4.1 \\
\hline & Total & 403.7 & 407.2 & 354.7 & 269.3 & -0.3 & 10.5 & 19.7 \\
\hline
\end{tabular}

Sources: Planning Commission of India; IMF staff calculations.

1/ Data for 2011/12 based on the Planning Commission of India's Press Note on Poverty Estimates, 2011-12, July 2013.

States differ markedly on poverty incidence (Figure 6). Bihar, Orissa, Uttar Pradesh, and Madhya Pradesh were above the national poverty rate in 2004/05 and 2009/10, accounting for nearly half of the total poor in India (170 million out of 355 million poor in 2009/10). In 2004/05, these states accounted for nearly 43 percent of the poor (176 million out of 407 million poor). Between 2004/05 and 2009/10, while the poverty rate in Assam increased above the national poverty rate, the poverty rate in Maharashtra fell below the national

\footnotetext{
${ }^{6}$ The poverty line refers to the poverty line computed using Tendulkar committee methodology, which represents the official poverty line used by the Planning Commission of India.

${ }^{7}$ It should be noted that India's progress on poverty reduction has been documented extensively, and some debate, in part regarding poverty headcount measurement issues, remains unresolved. For further discussion see Deaton and Kozel (2005) and Bhagwati and Panagariya (2012; 2013).

${ }^{8}$ Given that 2009/10 was a severe drought year, the NSSO repeated the large scale survey in 2011/12.
} 
poverty rate. Moreover, between 2009/10 and 2011/12, poverty headcount rates declined across all of the major states. As well, the number of poor went down in all states, including in each state's urban and rural areas. Furthermore, several states with high poverty rates, namely Bihar and Uttar Pradesh witnessed sharp declines in poverty headcount rates during this period. However, four states, namely Bihar, Orissa, Madhya Pradesh, and Uttar Pradesh, continue to account for nearly half of India's poor.

Figure 6: Regional Poverty Rates
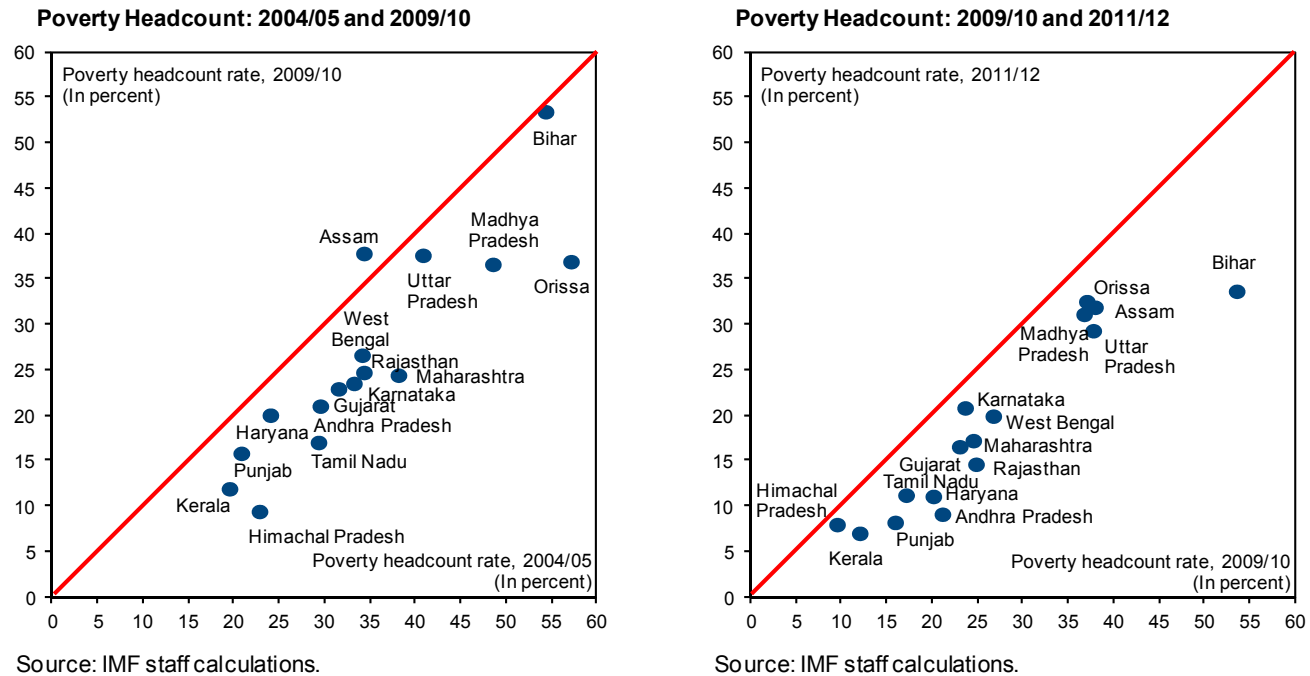

Figure 7: Regional Poverty Reduction Progress
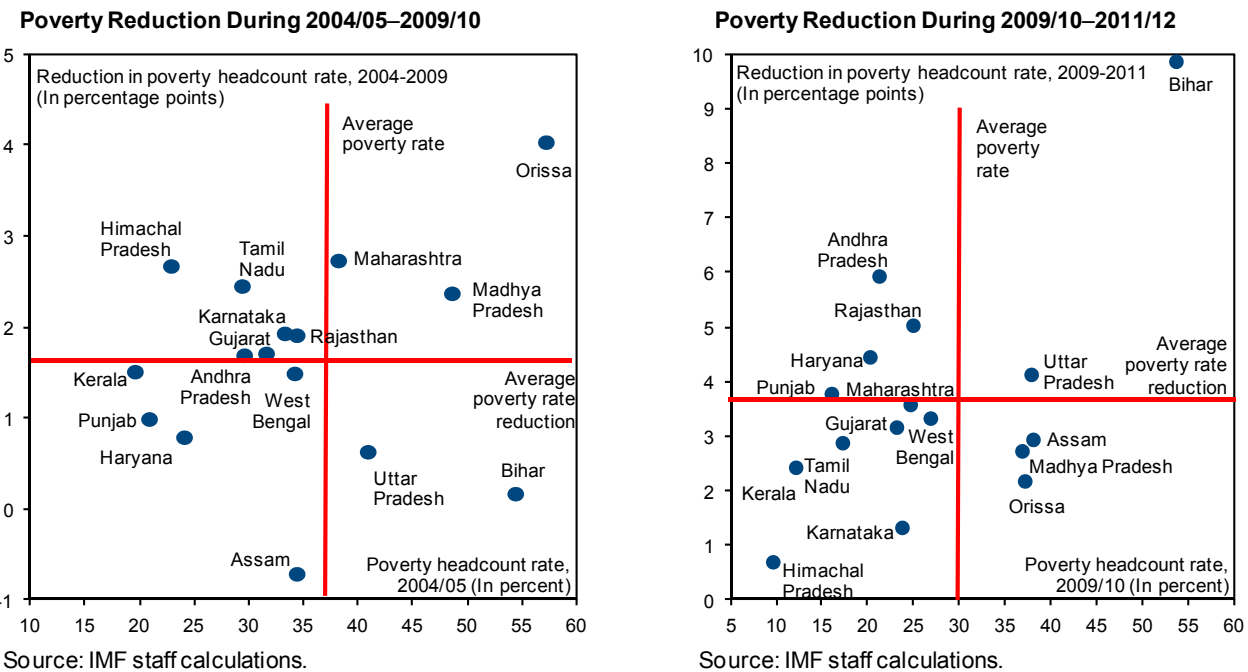

The four poor states (Bihar, Orissa, Uttar Pradesh, and Madhya Pradesh) saw only 6 million people move out of poverty during 2004/05-2009/10. However, during 2009/10-2011/12, the poverty headcount in these four states declined by almost 37 million people. While Orissa and Madhya Pradesh saw large poverty reduction during 2004/05-2009/10, other poor states —Assam, Bihar, and Uttar Pradesh—witnessed a much slower reduction in poverty (Figure 7 
and Table 3). In fact, the number of people living below the poverty line went up by 75 million in these states during 2004/05-2009/10. Moreover, during this period most of the increase in people living below poverty line in Bihar and Assam occurred in rural areas. Nevertheless, it appears that the trend reversed during 2009/10-2011/12, as 34 million people came out of poverty in these states. Encouragingly, rural poverty headcount in Bihar and Assam declined by almost 20 million people. At the same time, states with lower poverty rates - Maharashtra, Himachal Pradesh, Tamil Nadu, and Rajasthan — continued to witness a rapid decline in poverty.

Table 3. India: Average Decline in Poverty Headcount Rate by State, 16 Major States (In percentage points per year)

\begin{tabular}{|c|c|c|c|c|c|c|c|c|c|}
\hline & Rural & Urban & Total & Rural & Urban & Total & Rural & Urban & Tota \\
\hline Assam & 1.68 & 0.54 & 1.58 & -0.70 & -0.86 & -0.70 & 3.00 & 2.80 & 2.95 \\
\hline Bihar & 0.60 & 0.09 & 0.55 & 0.08 & 0.86 & 0.18 & 10.65 & 4.10 & 9.90 \\
\hline Himachal Pradesh & 1.06 & 0.82 & 1.06 & 3.18 & -1.60 & 2.68 & 0.30 & 4.15 & 0.70 \\
\hline Karnataka & 1.74 & 0.75 & 1.46 & 2.28 & 1.26 & 1.96 & 0.80 & 2.15 & 1.35 \\
\hline Kerala & 1.25 & 0.50 & 1.05 & 1.64 & 1.26 & 1.54 & 1.45 & 3.55 & 2.45 \\
\hline Madhya Pradesh & -0.42 & -0.30 & -0.36 & 2.32 & 2.44 & 2.38 & 3.15 & 0.95 & 2.50 \\
\hline Maharashtra & 1.04 & 0.43 & 0.88 & 3.68 & 1.46 & 2.72 & 2.65 & 4.60 & 3.55 \\
\hline Tamil Nadu & 1.23 & 1.27 & 1.43 & 3.26 & 1.38 & 2.36 & 2.70 & 3.15 & 2.90 \\
\hline Uttar Pradesh & 0.75 & 0.38 & 0.68 & 0.66 & 0.48 & 0.64 & 4.50 & 2.80 & 4.15 \\
\hline West Bengal & 0.39 & 0.62 & 0.46 & 1.88 & 0.48 & 1.52 & 3.15 & 3.65 & 3.35 \\
\hline All India & 0.75 & 0.55 & 0.74 & 1.60 & 0.96 & 1.48 & 4.05 & 3.60 & 3.95 \\
\hline
\end{tabular}

Source: IMF staff calculations.

Consumption-based inequality increased during 2004/05-2009/10 — rural India's Gini index increased from about 0.27 to 0.28 and from 0.35 to 0.37 in urban areas. This rise in inequality can be attributed to three key reasons: (i) the widening of inter-state income variation; (ii) growing nationwide as well as intrastate disparity between urban and rural consumption; and (iii) generally higher urban and to a lesser extent higher intra-state rural inequality.

In terms of income, the gap between states has widened, resulting in higher nationwide income inequality. ${ }^{9}$ Although the poorer states grew faster during 2004/05-2009/10 than during the

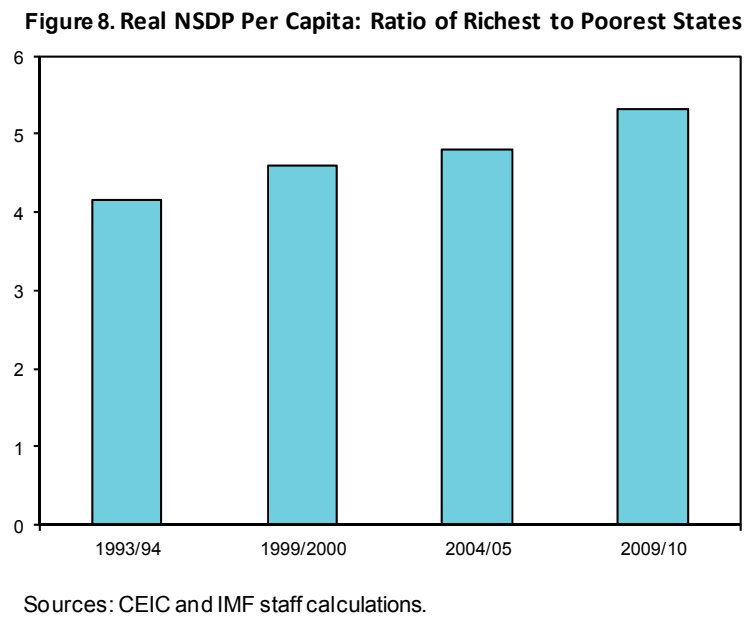

\footnotetext{
${ }^{9}$ Income per capita is measured as net state domestic product per capita.
} 
previous period, the rich states grew even faster, resulting in a widening of the gap between the richest and the poorest states. The gap in real per capita income levels between the rich and poor states has widened steadily during 1993/94-2009/10 (Figure 8) - rising to 5.3 in $2009 / 10$ from 4.2 in 1993/94. However, the gap has widened sharply during 2004/05$2009 / 10$, increasing from 4.8 in $2004 / 05$ to 5.3 in 2009/10.

The gap between rural and urban consumption has increased. The widening of the ratios of urban to rural consumption across most states during 2004/052009/10 resulted in the widening of the nationwide disparity between urban and rural consumption (Figure 9). It appears that the ratio between urban and rural consumption increased the most in states in which it was already high (Karnataka and Maharashtra). Although in several states, which experienced above average consumption growth, namely Kerala, Himachal Pradesh and Tamil Nadu, the ratio declined, reflecting relatively strong growth of rural consumption.

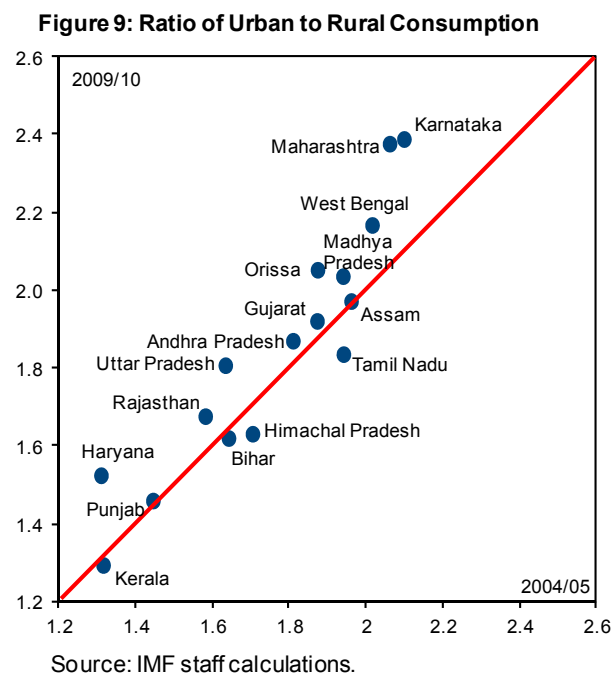

In addition, inequality appears to have also increased at the intrastate level. In terms of Gini coefficient (based on consumption, using the Mixed Reference Period (MRP) methodology), inequality in the rural areas in 9 out of the 16 states - increased marginally from 0.266 in $2004 / 05$ to 0.276 in $2009 / 10$ (Figure 10). However, the inequality increased in the urban areas from 0.348 in $2004 / 05$ to 0.371 in $2009 / 10$. The urban Gini coefficient declined in only two states - Tamil Nadu and Uttar Pradesh (Figure 11).
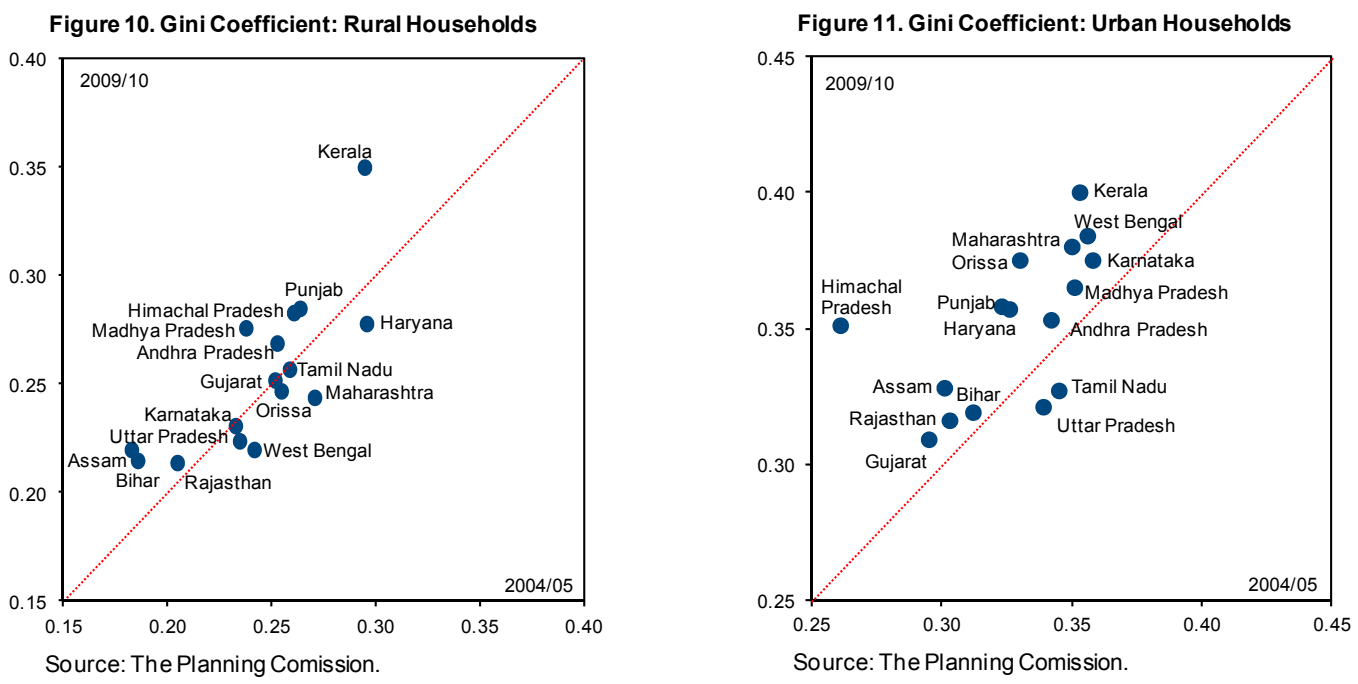


\section{Analysis of Poverty Reduction and Inequality}

In this section, we place our analysis of poverty reduction and inequality in perspective by analyzing the role of growth and inequality in poverty reduction. This analysis relies on the data for 2004/05-2009/10.

First, we perform the Datt-Ravallion Growth-Inequality decomposition (Datt and Ravallion, 1992) that quantifies the relative contributions of economic growth and redistribution with regard to changes in poverty. Specifically,

$$
P_{t+1}-P_{t}=G(t, t+1)+D(t, t+1)+R(t, t+1)
$$

where $P_{t+1}-P_{t}$ represents change in poverty headcount between period $t$ and $t+1$. The growth component $G$ represents the change in poverty attributable to the growth of average welfare when the income distribution is held constant and corresponds to the distribution in the base year $t$. The redistribution component $D$ in turn represents the change in poverty attributable to shifts in the distribution curve holding mean welfare constant and equal to its level in the base year $t$. Finally, $R$ represents the residual term, which is generally negligible in magnitude and which represents the effect of simultaneous changes in mean welfare and distribution on poverty.

Figure 12 depicts the per capita real expenditure distribution of the 16 major states. We normalize each person's nominal expenditure by the level of the urban or rural state-specific poverty line in 2004/05 and 2009/10, so that the level of real per capita expenditure of 100 denotes expenditure equal to the level of household-specific poverty line. Thus the blue and red lines denote real expenditure distributions in 2004/05 and 2009/10, respectively. As we can see, the shift between the two periods, for the population as a whole, was to a large extent due to growth component (Figure 12) as the red line which denotes the actual 2009/10 distribution is closely lined up with the black line denoting the growth component.

Figure 12. Comparison of Growth and Inequality Contribution to Poverty Recution

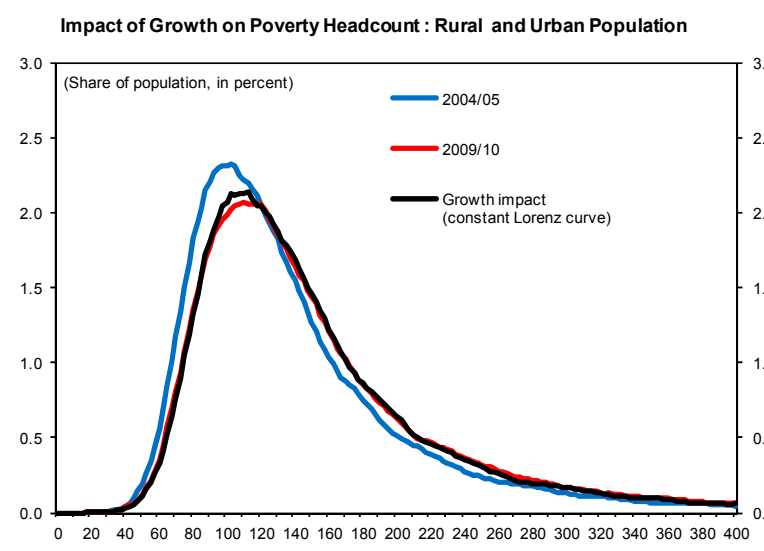

Impact of Redistribution on Poverty Headcount : Rural and Urban Population

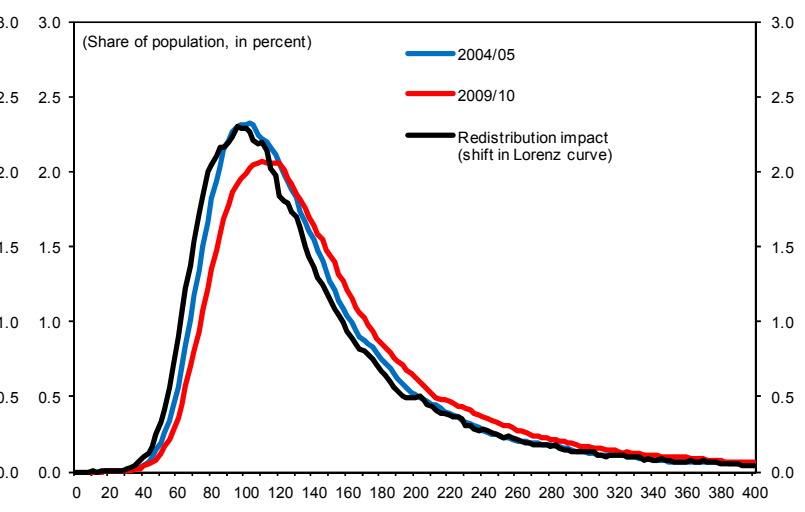

$($ Real expenditure per capita, poverty line $=100$

(Real expenditure per capita, poverty line $=100$ )

Source: IMF staff estimates. 
However, the contributions of distribution shifts and growth differed dramatically between the rural and urban population. As can be seen from the top two charts on Figure 13, the distribution shift contributed positively to poverty reduction among rural households, while it worked against poverty reduction among urban households. While the growth contribution provided for about a 3 percentage point larger decline in poverty headcount among urban relative to rural households, this differential was more than offset by a nearly 6 percentage point differential from the adverse shift in the welfare distribution. As well, it appears that the negative impact of redistribution affected the poorest urban households disproportionately more. Specifically, about four fifths of the redistribution change in poverty was concentrated in the bottom quartile of the urban poor, those with expenditures below two thirds of the poverty line (bottom right chart in Figure 13). On the other hand, most of the gains from distribution change in rural poverty headcount occurred among the poorest rural households. Specifically, nearly half of the impact from distributional shift in rural poverty reduction could be attributed to the bottom quartile of the rural poor, those who lived below two thirds of the poverty line in 2004/05 (bottom left chart on Figure 13).

Figure 13. Comparison of Growth and Inequality Contributionsto Poverty Reduction Between Rural and Urban Households

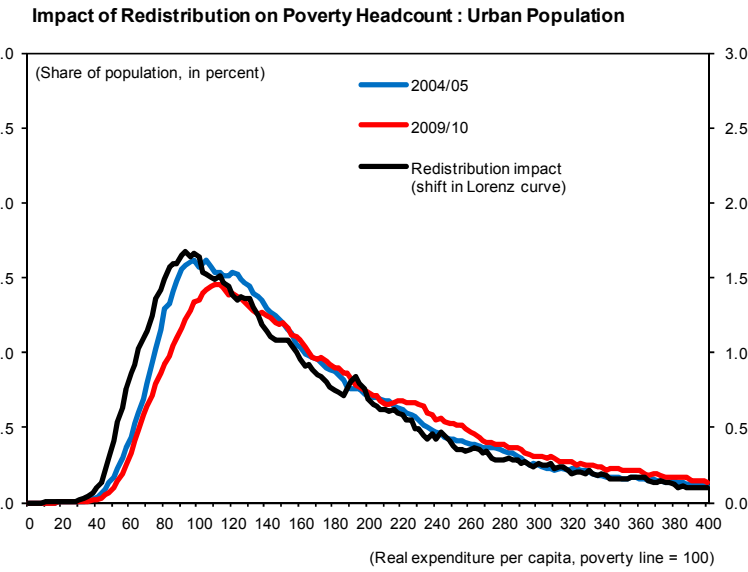

Impact of Redistribution on Poverty Headcount : Rural Population

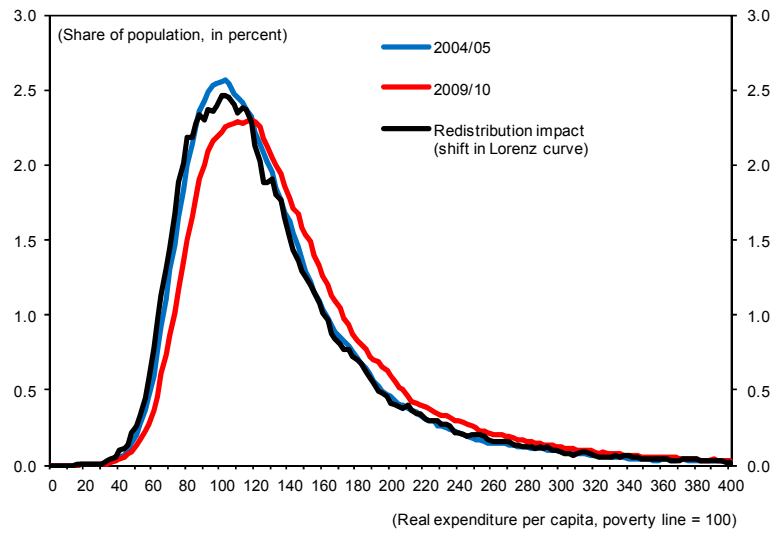

Cumulative Impact on Poverty Reduction: Urban Population

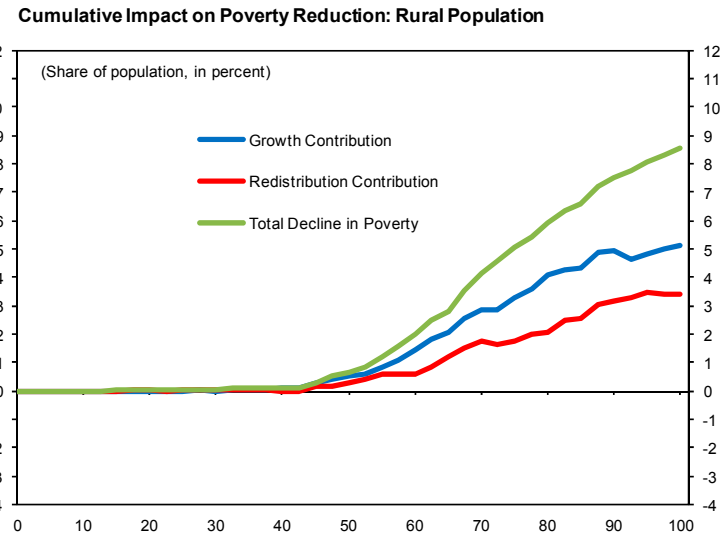

Source: IMF staff estimates. 
Nevertheless, it should be noted that all segments of the rural and urban poor appeared to have experienced a boost in real expenditures (suggested by the increasing green lines in the bottom charts of Figure 13). Thus, the redistribution component in the Datt-Ravallion decomposition is simply a reflection of the fact that different segments of the population experienced different welfare growth. In order to analyze this deeply, we look at an alternative way of characterizing developments in inequality, namely the analysis of growth incidence curve.

Figure 14 depicts the difference in real expenditure growth across different segments of the welfare distribution. ${ }^{10}$ It is apparent that richer households have generally experienced higher growth. Also, the average expenditure growth experienced by all households (violet line), that is, if we do not take into account initial differences in the level of expenditure, was about 1.5 percentage points lower than the average growth of real expenditure across all households. In other words, only about onesixth of total households' expenditure grew by more than the population average and only about one third grew in excess of the average growth rate per household. Nevertheless, it does appear that some relatively poor households (those in the segment between the $25^{\text {th }}$ and $35^{\text {th }}$ percentile of the distribution) did experience somewhat stronger growth than some of the more well off households.

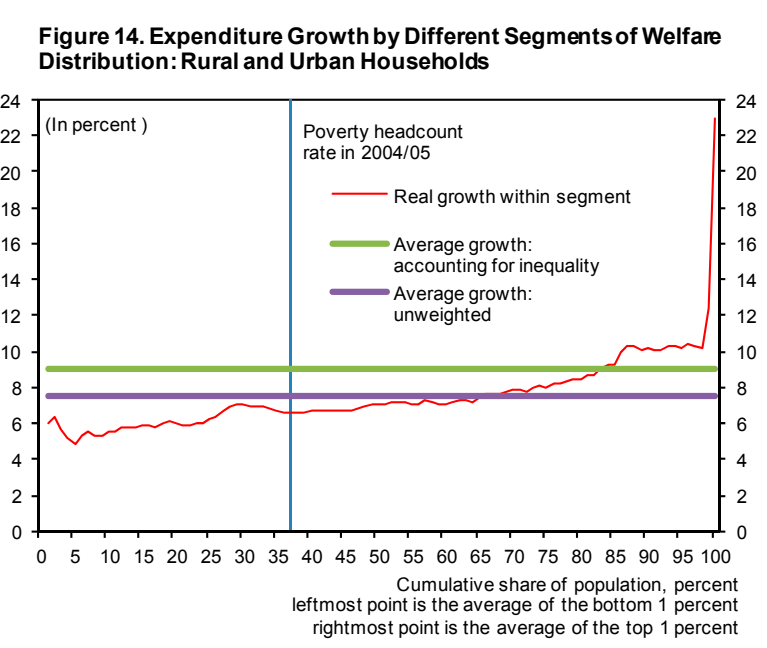

Source: IMF staff estimates.

However, there are noticeable differences between the growth incidence curves of rural and urban households (Figure 15). Rural households experienced a remarkably uniform growth distribution compared with urban households. Also, given a more equal initial distribution, the difference between the two measures of average expenditure growth among the rural households was negligible. In addition, the households around the poverty line (both above and below) experienced above-average growth. This seems to reflect the fact that the most well-off households experienced much lower growth. In contrast, growth variation among urban households appears to be very high. Only the richest 5 percent of urban population experienced growth above the average urban expenditure growth, while growth among households below the poverty line was significantly lower.

\footnotetext{
${ }^{10}$ An alternative presentation of the growth incidence curve involves the horizontal axis showing real expenditure level. However, such a representation does not inform about the distribution of welfare.
} 
Figure 15. Comparison of Growth Incidence Curve Between Rural and Urban Households
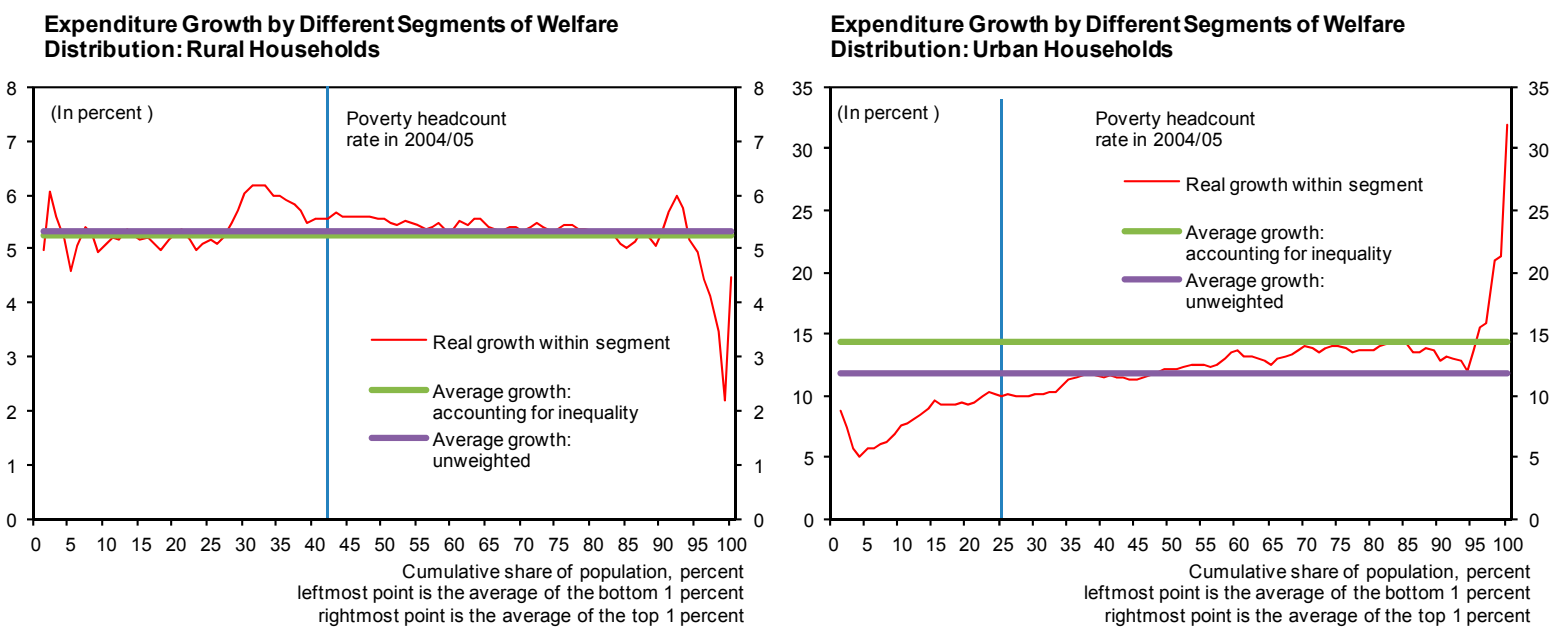

Source: IMF staff estimates.

In this section, we documented the changes in growth and inequality over time. In the next section, we bring our analysis together and examine the evolution of inclusive growth during 2004/05-2009/10.

\section{INCLUSIVE GROWTH}

\section{A. Defining Inclusive Growth}

Inclusive growth refers to both the pace and distribution of economic growth. In order for growth to be sustainable and effective in reducing poverty, it needs to be inclusive (Berg and Ostry, 2011; and Kraay, 2004). Traditionally, poverty (or inequality) and economic growth analyses have been done separately. ${ }^{11}$ In this paper we use a measure developed by Anand and others (2013), which integrates the two strands of analysis by developing a unified measure of inclusive growth. ${ }^{12}$ The construction and features of this measure is summarized below.

The measure is based on a utilitarian social welfare function, where inclusive growth depends on two factors: (i) income growth; and (ii) income distribution. The underlying social welfare function satisfies two properties to capture these features: (i) it is increasing in its argument (to capture the growth dimension) and (ii) it satisfies the transfer property - any transfer of

\footnotetext{
${ }^{11}$ See, for example, IMF (2007).

${ }^{12}$ See, Anand and others (2013) for the details of this measure.
} 
income from a poor person to a richer person reduces the value of the function (to capture distributional dimension). Anand and others (2013) use the concept of a concentration curve to define inclusiveness and define a social mobility curve, $S^{C}$, such that:

$$
S^{C} \approx\left(y_{1}, \frac{y_{1}+y_{2}}{2}, \ldots \ldots \ldots, \frac{y_{1}+y_{2}+\cdots y_{n}}{n}\right)
$$

where $n$ is the number of persons in the population with incomes $y_{1}, y_{2}, \ldots \ldots, y_{n}$, where $y_{1}$ is the poorest person and $y_{n}$ is the richest person. ${ }^{13}$ Since $S^{C}$ satisfies the transfer property, a superior income distribution will always have a higher generalized concentration curve. Similarly, since it is increasing in its argument, higher income will also have a higher generalized concentration curve.

To derive these curves, the population is arranged in the ascending order of their income. Here $\bar{y}_{i}$ is the average income of the bottom $i$ percent of the population, where $i$ varies from 0 to 100 and $\bar{y}$ is the mean income. Average income $\bar{y}_{i}$ for different values of $i$ is plotted to get the social mobility curves (curve AB in Figure 16 below). Curve AB represents the social mobility curve discussed above. Since a higher curve implies greater social mobility, growth is inclusive if the social mobility curve moves upward at all points. However, there may be degrees of inclusive growth depending on: (i) how much the curve moves up (growth); and (ii) how the distribution of income changes (equity). This feature of the social mobility curve is the basis of an integrated measure of inclusive growth. Thus, if two generalized concentration curves do not intersect, they could be ranked on social mobility, that is inclusiveness of growth.

Figure 16 depicts two social mobility curves with the same average income $(\bar{y})$ but different degrees of inclusiveness (i.e., different income distribution). Social mobility curve $\left(\mathrm{A}_{1} \mathrm{~B}\right)$ is more inclusive than the social mobility curve $\mathrm{AB}$, as the average income of the bottom segment of the society is higher.

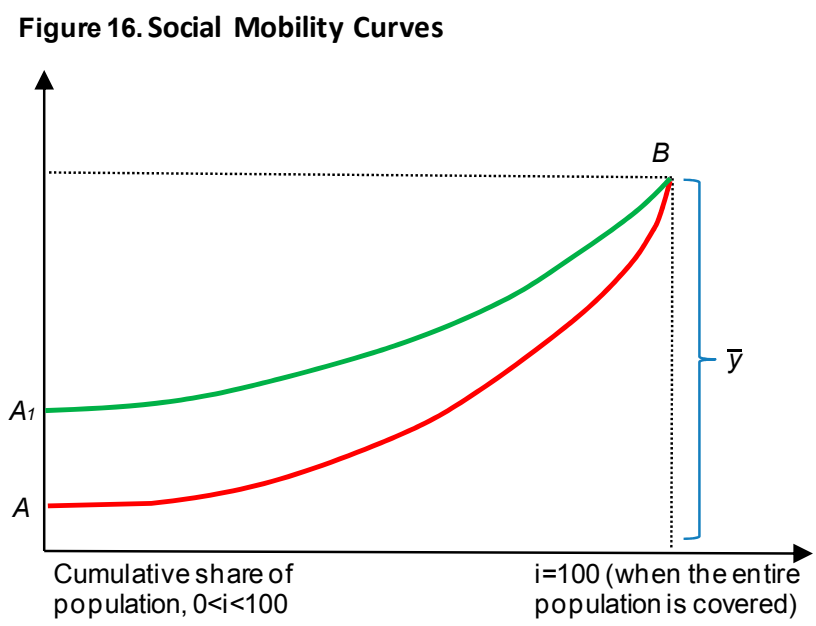

${ }^{13}$ See Ali and Son (2007) for details. 
To capture the magnitude of the change in income distribution, Anand and others (2013) proposed an index calculated from the area under the social mobility curve:

$$
\bar{y}^{*}=\int_{0}^{100} \bar{y}_{i} d i
$$

The greater is $\bar{y}^{*}$, the greater is the income. If the income of everyone in the population is same (i.e., if income distribution is completely equitable) then $\bar{y}^{*}$ will be equal to $\bar{y}$. If $\bar{y}^{*}$ is lower than $\bar{y}$, it implies that the distribution of income is inequitable. So, the deviation of $\bar{y}^{*}$ from $\bar{y}$ is an indication of inequality in income distribution.

Using this feature of $\bar{y}^{*}$, an income equity index $(\omega)$ is defined as follows:

$$
\omega=\frac{\bar{y}^{*}}{\bar{y}}
$$

For a completely equitable society, $\omega=1$. Thus, a higher value of $\omega$ (closer to one) represents higher income equality. Rearranging,

$$
\bar{y}^{*}=\omega * \bar{y}
$$

Inclusive growth requires increasing $\bar{y}^{*}$, which could be achieved by: (i) increasing $\bar{y}$, i.e., increasing average income through growth; (ii) increasing the equity index of income, $\omega$, through increasing equity; or (iii) a combination of (i) and (ii). Also,

$$
d \bar{y}^{*}=\omega * d \bar{y}+d \omega * \bar{y}
$$

where $d \bar{y}^{*}$ is the change in the degree of inclusive growth. ${ }^{14}$ Growth is more inclusive if $d \bar{y}^{*}>0$. Equation (2) also allows us to decompose inclusive growth into income growth and the change in equity. The first term is the contribution of the increase in average income (keeping income distribution constant) while the second term is the contribution of changes in the income distribution (keeping the average income unchanged).

Inclusive growth depends on the sign and the magnitude of the two terms. Graphically, Figure 17 below illustrates all possible combinations of the two terms. If both terms are positive $(d \bar{y}>0, d \omega>0)$, growth is unambiguously inclusive (AB shifting to A1B1 in Figure 17); similarly, if both terms are negative $(d \bar{y}<0, d \omega<0)$, growth is unambiguously non-inclusive (AB shifting to A4B4). However, there could be trade-offs between $\bar{y}$ and $\omega$. If

\footnotetext{
${ }^{14}$ Inclusive growth is defined as the change in the social mobility index $d \bar{y}^{*}$, which is used interchangeably in this paper.
} 
the first term is positive, but the second term is negative, higher inclusiveness is achieved at the expense of reduction in equity; in Figure 17, this case can be illustrated by the shift of the social mobility curve from AB to A2B2. Similarly, if the first term is negative but the second term is positive, then higher inclusiveness is achieved at the cost of contraction in average income: in Figure 17, this case can be illustrated by the shift of the social mobility curve from $\mathrm{AB}$ to $\mathrm{A} 3 \mathrm{~B} 3$.

Equation (2) could also be rearranged as:

$$
\frac{d \bar{y}^{*}}{\bar{y}^{*}}=\frac{d \bar{y}}{\bar{y}}+\frac{d \omega}{\omega}
$$

This is the fundamental relation integrating growth and equity into one measure of inclusive growth (percent change in $\bar{y}^{*}$ ) that we use in our subsequent analysis to illustrate the evolution of inclusive growth and the relative contributions of growth and equity. It decomposes inclusive growth into growth and the percentage change in equity, measured by $\omega .^{15}$

Figure 17. Shifts in Social Mobility Curve

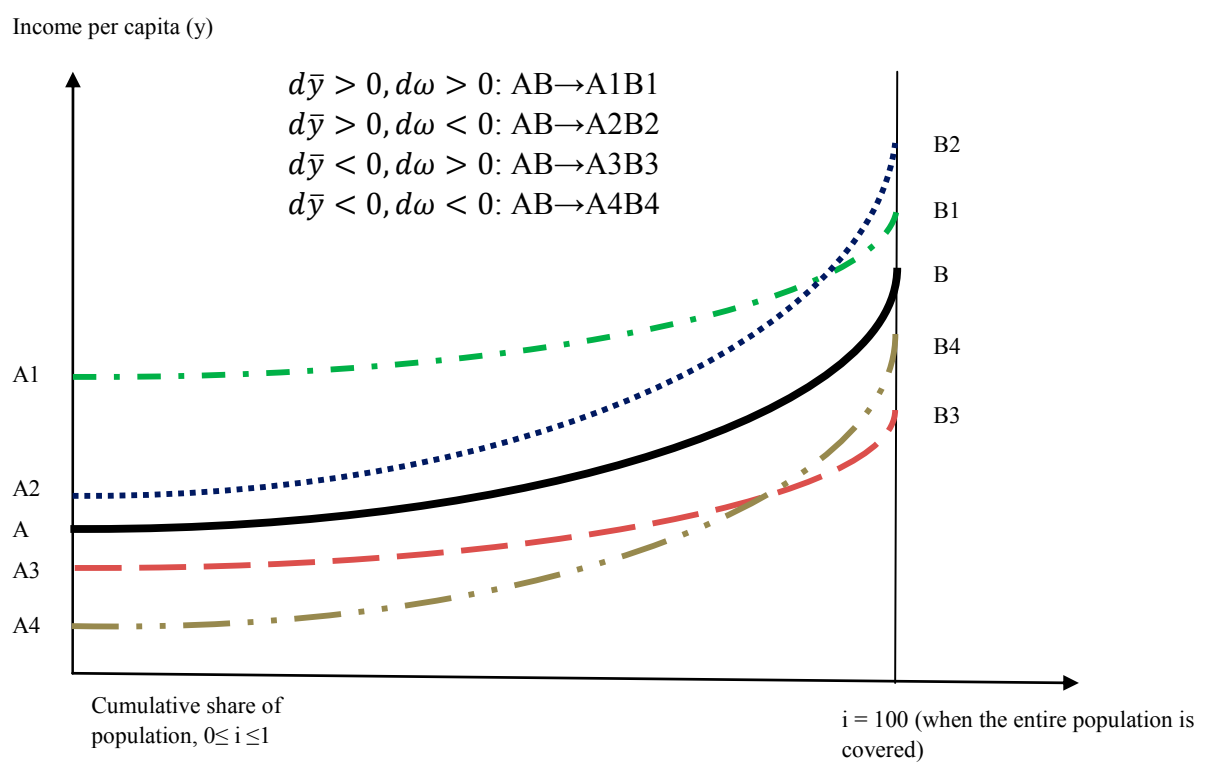

\footnotetext{
${ }^{15}$ It should be noted that this inclusive growth measure already assigns a decreasing weight to higher income groups. For example, if a rupee is transferred from the 10th decile to the 1 st decile, inclusiveness $\left(\bar{y}^{*}\right)$ and equity $(\omega)$ increase by more than if a rupee is transferred from the 10 th decile to the 2 nd decile and so on.
} 


\section{B. Evolution of Inclusiveness}

Inclusive growth (measured by the change in $\bar{y}^{*}$, defined in the previous section) fell short of growth in average consumption over 2004/05-2009/10, reflecting a deterioration of inclusiveness components, primarily on account of rising urban-rural and intra-urban inequality. As can be seen from column (11) in Table 4, the 16-state aggregate consumptionbased inclusive growth averaged just 1.3 percent per year over 2004/09-2009/10 compared to about 1.8 percent growth in average consumption. However, inclusive growth in rural India slightly exceeded average consumption growth (as can be seen from columns (11) and (12) in Table 4) suggesting a marginal improvement in equity in rural areas. However, it averaged only slightly above 1 percent per year, thus falling short of a near 2 percent inclusive growth rate in urban areas. Moreover, the inclusive growth in urban India was below average consumption growth, reflecting growing intra-urban inequality. Thus, as a result of a growing consumption disparity between rural and urban households, augmented by a rise in intra-urban inequality, inclusive growth at the national level has been below overall average consumption growth. The growing urban-rural disparity is also reflected in the deterioration of the inclusiveness component for all India inclusive growth measures (top row of column 13) which appears disproportionately larger than the decline in overall urban inclusiveness would explain, given an urbanization rate of about 30 percent.

Reflecting the rising urban-rural divide, inclusive growth fell short of average consumption growth in 13 major states, in 10 of which, rural consumption growth lagged urban consumption growth. Of the three states with consumption growth below inclusive growth, Haryana and West Bengal had inclusive growth and average consumption growth significantly below state-wise averages. Only Tamil Nadu stands out as having made above average progress with respect to inclusive growth as well as its components. The poorest inclusive growth performing states - Assam and Bihar-had negative inclusive growth reflecting widening inequality. Nonetheless, these results should be treated with caution in light of data issues in the 2009/10 NSSO household survey. In each of these two states, average consumption growth rate was among the weakest of the 16 major states, while deteriorating equity reduced it further by almost 1 percentage point per year over 2004/052009/10. 
Table 4. India: Progress on Growth, Poverty Reduction and Inequality. Summary Table for 16 Major States

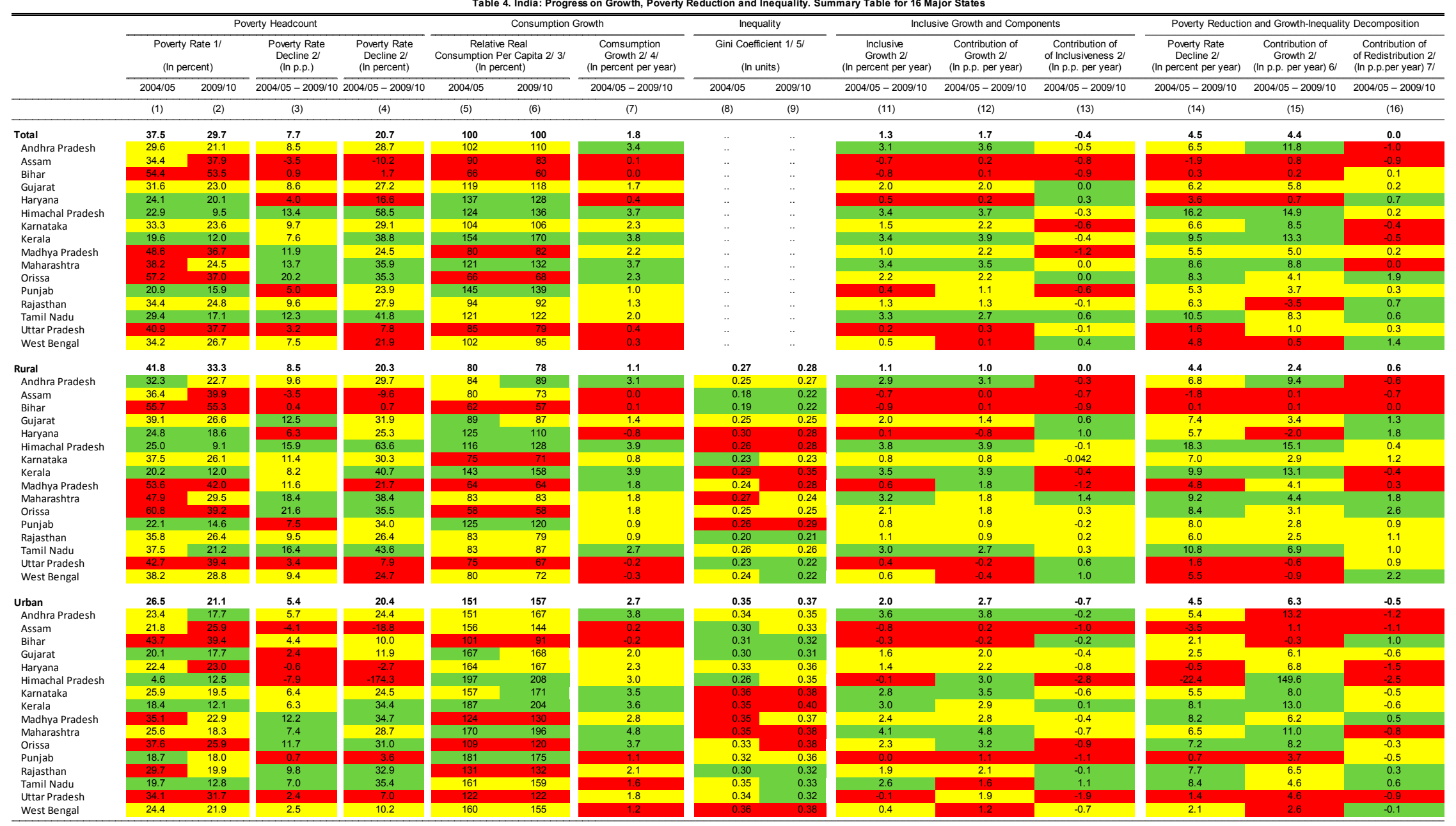

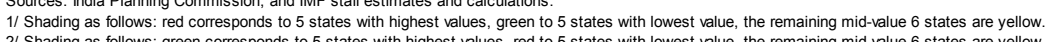

2/ Shading as follows: green corresponds to 5 states with highest values, red to 5

4/ Real per capita consumption, average annual percent change. Based on $2004 / 05$ state population weights.

$5 /$ Consumption-based using Mixed Reference Period (MRP) methodology.
6 / In percentage points of average annual percent decline in poverty headcount rate.

$6 /$ In percentage points of average annual percent decline
$7 /$ In percetnage points of $2004 / 05$ poverty headcount rate. 


\section{ECONOMETRIC ANALYSIS OF GROWTH INCLUSIVENESS}

An analysis is conducted using state-level panel data to determine whether macroeconomic and financial conditions as well as public policies (e.g., government social spending, educational attainment, financial development) have empirical significance in explaining growth inclusiveness. By exploiting the variations in growth inclusiveness outcomes across states and over time, we attempt to uncover the state characteristics associated with stronger and more inclusive growth. We follow the panel data approach exploited in the previous studies of economic growth and poverty reduction across Indian states (Purfield, 2006; and Topalova, 2008).

However, as our data set spans four NSSO surveys (1993/94, 1999/2000, 2004/05, and 2009/10), we can construct only three growth observations per state, so we chose to omit state fixed effects. Given a relatively small time dimension, this empirical strategy aims to reflect on the average cross-sectional variation in the explanatory variables, which otherwise would be fully attributed to the state fixed effects. On the other hand, we might attribute the effects of some potentially important time-invariant state characteristics, such as resource endowments or socioeconomic and cultural factors, which are also correlated with policy variables in question, to the effect of policy variables themselves. We thus estimate:

$$
g_{t, s}=\propto+\beta X_{t, s}+\tau_{t}+\varepsilon_{t, s}
$$

In the baseline specification, $g_{t, s}$ is the measure of average annual inclusive growth in state $S$ between two consecutive NSSO survey periods $t$ and $t-1$. As well, we analyze two components of our inclusive growth measure: (i) the growth of average expenditure per capita $(\bar{y})$ and (ii) the contribution of equity $(\omega)$. The three periods considered are 1993/941999/2000, 1999/2000-2004/05, and 2004/05-2009/10. ${ }^{16}$ The vector $X_{t, s}$ spans various statelevel characteristics, which across the econometric specifications considered include variables that represent inter-period changes in underlying characteristics and/or current period or previous period levels of these characteristics. For simplicity of presentation, the subscript $t$ thus unifies such differences in the reference measurement period to correspond to the dependent variable. Finally, $\tau_{t}$ represents period fixed effects. For each of the periods, the data are available for all 16 states.

We begin by investigating inclusive growth performance across states (combined urban and rural population). Given the rise in urban-rural inequality, we then turn to analyze cross-state inclusive growth performance for urban and rural populations separately. We complement the econometric analysis with regressions of Datt-Ravallion poverty-reduction decomposition to illustrate the link between these two concepts.

\footnotetext{
${ }^{16}$ As the first period spans a six year interval while the other two are five years long, we adjust the variables to annual rates when necessary.
} 
In the baseline specifications presented in columns (1), (4) and (7) of Table 5, the dependent variable measures inclusive growth, average expenditure growth and the contribution of equity component to inclusive growth, respectively. The set of independent variables includes the state level bank credit-to-GDP ratio; level of real state social spending per capita; and the state's rate of inflation. The results indicate that states with higher social sector spending, a deeper financial sector, and lower inflation experienced higher inclusive growth.

Some interesting results emerge as we compare the relationship of these variables with the two components of inclusive growth. Higher social spending is associated with higher average growth of household consumption expenditure, but its link with the redistribution component of inclusive growth is statistically insignificant. It seems to suggest that states' overall social services spending is reaching out to a broad spectrum of population, helping the majority rather than helping through redistribution. Moreover, when poverty incidence was high — as in 1993/94 when the national poverty headcount rate exceeded 45 percenthigher social spending worked through lifting up the majority of population rather than through redistribution toward relatively poor households.

The adverse link between inclusive growth and inflation acts primarily through the impact on average expenditure growth. It appears that even though inflation tends to hurt the poorer disproportionately more, when poverty is so widespread, most of the population becomes affected.${ }^{17}$ Also, the statistical significance of the inflation coefficients in the equity component specification appears very close to the conventional 10 percent confidence band.

Finally, we find that states with higher levels of bank credit-to-GDP ratios appear to have experienced higher inclusive growth. The role played by credit can be seen through its strong impact on the average consumption growth component. The linkage of financial deepening to the equity component is positive but not statistically significant.

The second and third specifications for inclusive growth as well as its components presented in Table 5 examine their connection with education-related variables. Education is often considered a primary weapon to fight against poverty. However, it has been also recognized that appropriate labor market and structural conditions and policies play a critical role in enabling more education attainment to enhance and broaden economic growth. As such, our inclusiveness growth measure amalgamates several important findings regarding the impact of education on economic growth and inclusiveness. The positive association of initial education levels and subsequent economic growth has been widely documented (Barro, 1991; Benhabib and Spiegel, 1994). However, debate on the effects of increase in education on economic growth is inconclusive (Benhabib and Spiegel,1994; and Pritchett, 2001).

\footnotetext{
${ }^{17}$ When we include among the explanatory variables the interaction term for poverty and inflation, we find that, controlling for inflation, higher poverty, and higher inflation together are associated with less inclusive growth.
} 
In columns (2), (5), and (8) we include the change in the ratio of state spending on education to state net domestic product. As indicated in column (8), states that boosted spending on education over time had a positive contribution from the equity component outcomes but did not experience stronger average consumption growth. As well, the impact of states' education spending on inclusive growth does not appear statistically significant either.

In columns (3), (6) and (9) we control for both the initial level of education, specifically the average literacy rate for each state's population, as well as for inter-period change in literacy. We find that both the initial level and change in education matter for inclusive growth. Both also matter for the average consumption growth (column 6), while for the inclusiveness component only increase in literacy variable seems to matter (column 9).

Also, the levels of statistical significance and magnitudes of coefficients on credit-to-GDP ratio, inflation, and social spending variables are generally consistent across all specifications. Nonetheless, the magnitude and significance of the social spending coefficient in explaining average expenditure growth declines somewhat in specifications with the education variable, suggesting a possible link between states' social spending and literacy outcomes. ${ }^{18}$

\begin{tabular}{|c|c|c|c|c|c|c|c|c|c|}
\hline \multirow[t]{2}{*}{ Dependent Variable: } & \multicolumn{3}{|c|}{$\begin{array}{l}\text { Inclusive growth } \\
\text { In percent per year }\end{array}$} & \multicolumn{3}{|c|}{$\begin{array}{l}\text { Average expenditure component } \\
\text { In percent per year }\end{array}$} & \multicolumn{3}{|c|}{$\begin{array}{l}\text { Inclusiveness component } \\
\text { In percent per year }\end{array}$} \\
\hline & (1) & $(2)$ & (3) & (4) & (5) & (6) & (7) & (8) & (9) \\
\hline $\begin{array}{l}\text { Credit-to-GDP ratio } \\
\quad \text { In percent, period average }\end{array}$ & $\begin{array}{l}0.019^{* *} \\
(0.008)\end{array}$ & $\begin{array}{l}0.019^{* *} \\
(0.009)\end{array}$ & $\begin{array}{l}0.020 \text { ** } \\
(0.008)\end{array}$ & $\begin{array}{l}0.013 * \\
(0.007)\end{array}$ & $\begin{array}{l}0.013^{*} \\
(0.007)\end{array}$ & $\begin{array}{r}0.011 \\
(0.008)\end{array}$ & $\begin{array}{r}0.005 \\
(0.005)\end{array}$ & $\begin{array}{r}0.005 \\
(0.004)\end{array}$ & $\begin{array}{l}0.009 \text { ** } \\
(0.004)\end{array}$ \\
\hline $\begin{array}{l}\text { Real per capita state social sector expenditure } \\
\text { In percent of poverty line, average per year }\end{array}$ & $\begin{array}{l}0.025^{*} \\
(0.013)\end{array}$ & $\begin{array}{l}0.026 \text { * } \\
(0.014)\end{array}$ & $\begin{array}{l}0.023 \text { ** } \\
(0.011)\end{array}$ & $\begin{array}{l}0.026^{* \star} \\
(0.010)\end{array}$ & $\begin{array}{l}0.0222^{\star *} \\
(0.010)\end{array}$ & $\begin{array}{r}0.016 \\
(0.011)\end{array}$ & $\begin{array}{r}0.000 \\
(0.008)\end{array}$ & $\begin{array}{r}0.005 \\
(0.008)\end{array}$ & $\begin{array}{r}0.008 \\
(0.006)\end{array}$ \\
\hline $\begin{array}{l}\text { Inflation rate } \\
\qquad \text { In percent per year, period average }\end{array}$ & $\begin{array}{l}-0.724^{* \star *} \\
(0.207)\end{array}$ & $\begin{array}{l}-0.724^{\star \star *} \\
(0.209)\end{array}$ & $\begin{array}{l}-0.573^{* \star *} \\
(0.207)\end{array}$ & $\begin{array}{l}-0.564^{* * *} \\
(0.188)\end{array}$ & $\begin{array}{l}-0.563^{* * *} \\
(0.183)\end{array}$ & $\begin{array}{l}-0.444^{\star * *} \\
(0.193)\end{array}$ & $\begin{array}{l}-0.158 \\
(0.108)\end{array}$ & $\begin{array}{r}-0.159 \\
(0.103)\end{array}$ & $\begin{array}{r}-0.136 \\
(0.093)\end{array}$ \\
\hline $\begin{array}{l}\text { Increase in state spending on education } \\
\text { In percent of NSDP, over previous period's average }\end{array}$ & & $\begin{array}{r}0.096 \\
(0.425)\end{array}$ & & & $\begin{array}{r}-0.403 \\
(0.359)\end{array}$ & & & $\begin{array}{l}0.510 \text { * } \\
(0.227)\end{array}$ & \\
\hline $\begin{array}{l}\text { Increase in literacy rate } \\
\text { In percent per year }\end{array}$ & & & $\begin{array}{l}0.836^{* * *} \\
(0.278)\end{array}$ & & & $\begin{array}{l}0.5511^{* *} \\
(0.224)\end{array}$ & & & $\begin{array}{l}0.245^{* *} \\
(0.117)\end{array}$ \\
\hline $\begin{array}{l}\text { Literacy rate, end of previous period } \\
\text { In percent of state's total population }\end{array}$ & & & $\begin{array}{l}0.061 * * \\
(0.029)\end{array}$ & & & $\begin{array}{l}0.066 * * \\
(0.026)\end{array}$ & & & $\begin{array}{r}-0.010 \\
(0.012)\end{array}$ \\
\hline Number of observations & 48 & 48 & 48 & 48 & 48 & 48 & 48 & 48 & 48 \\
\hline $\mathrm{R}^{2}$ & 0.40 & 0.40 & 0.57 & 0.28 & 0.30 & 0.44 & 0.46 & 0.53 & 0.60 \\
\hline
\end{tabular}

Source: IMF staff estimates.

Note: Period dummies included, not reported in the table. Robust standard errors in parentheses.

Note: ${ }^{* * *},{ }^{* *},{ }^{*}$ indicates 1,5 , and 10 percent statistical significance, respectively.

\footnotetext{
${ }^{18}$ It also appears that the initial literacy rate and ratio of social services spending to GDP are very closely correlated, so that states with higher initial literacy rates appear to spend relatively more on social services in subsequent periods than states with lower initial literacy.
} 
Table 6 presents the results of similar econometric analysis to explain the components of the Datt-Ravallion decomposition of poverty reduction. We find that variables that are correlated with inclusive growth are generally also associated with poverty reduction. However, the statistical significance is generally weaker when compared to the regressions on inclusive growth.

First, there is a negative link between inflation and poverty reduction and its components. Similar to the econometric results for inclusiveness, higher inflation is associated with less poverty reduction, through lower average welfare growth as well as with an adverse contribution to distributional shifts. As inflation generally hurts poor households more, inflation should be negatively correlated with the redistribution channel of poverty reduction. In particular, poor households are usually more affected by food price inflation as they need to spend disproportionately more on food, and substitution possibilities are limited.

Therefore, they are generally more affected by inflation. Our state-level inflation measures used to deflate nominal consumption differ for rural and urban populations. However, within urban or rural households, inflation rates are uniform and thus cannot accommodate a potentially stronger impact of inflation on the welfare of the poorer households. Perhaps this explains why although of expected signs, these coefficients are not statistically significant. However, urban-rural inequality that results from urban-rural inflation differentials is likely to be a reason for the negative coefficient estimate on inflation in the equity component.

Coefficient estimates on the credit-to-GDP ratio are positive but statistically insignificant across all specifications. Similar to the inclusiveness regressions, we find a positive link between credit and the contribution of the redistribution channel to poverty reduction, which seems to suggest that broadening access to credit may be associated with inclusiveness and poverty reduction.

\begin{tabular}{|c|c|c|c|c|c|c|c|c|c|}
\hline \multirow[t]{2}{*}{ Dependent Variable: } & \multicolumn{3}{|c|}{$\begin{array}{l}\text { Poverty Reduction } \\
\text { In percent per year }\end{array}$} & \multicolumn{3}{|c|}{$\begin{array}{l}\text { Average expenditure component } \\
\text { In percent per year }\end{array}$} & \multicolumn{3}{|c|}{$\begin{array}{l}\text { Redistribution component } \\
\text { In percent per year }\end{array}$} \\
\hline & (1) & $(2)$ & (3) & (4) & (5) & (6) & (7) & (8) & (9) \\
\hline $\begin{array}{l}\text { Credit-to-GDP ratio } \\
\quad \text { In percent, period average }\end{array}$ & $\begin{array}{r}0.046 \\
(0.048)\end{array}$ & $\begin{array}{r}0.046 \\
(0.048)\end{array}$ & $\begin{array}{r}0.054 \\
(0.046)\end{array}$ & $\begin{array}{r}-0.009 \\
(0.030)\end{array}$ & $\begin{array}{r}-0.007 \\
(0.034)\end{array}$ & $\begin{array}{r}-0.031 \\
(0.039)\end{array}$ & $\begin{array}{r}0.025 \\
(0.031)\end{array}$ & $\begin{array}{r}0.024 \\
(0.032)\end{array}$ & $\begin{array}{r}0.038 \\
(0.030)\end{array}$ \\
\hline $\begin{array}{l}\text { Real per capita state social sector expenditure } \\
\text { In percent of poverty line, average per year }\end{array}$ & $\begin{array}{r}0.064 \\
(0.119)\end{array}$ & $\begin{array}{r}0.069 \\
(0.125)\end{array}$ & $\begin{array}{r}0.060 \\
(0.110)\end{array}$ & $\begin{array}{l}0.233^{* * *} \\
(0.052)\end{array}$ & $\begin{array}{l}0.199 * * * \\
(0.058)\end{array}$ & $\begin{array}{l}0.153^{* *} \\
(0.062)\end{array}$ & $\begin{array}{r}-0.099 \\
(0.076)\end{array}$ & $\begin{array}{r}-0.084 \\
(0.081)\end{array}$ & $\begin{array}{r}-0.069 \\
(0.072)\end{array}$ \\
\hline $\begin{array}{l}\text { Inflation rate } \\
\qquad \text { In percent per year, period average }\end{array}$ & $\begin{array}{l}-2.487^{\star *} \\
(0.998)\end{array}$ & $\begin{array}{l}-2.487^{\star *} \\
(1.014)\end{array}$ & $\begin{array}{l}-1.890 * \\
(1.027)\end{array}$ & $\begin{array}{r}-1.271 \\
(0.956)\end{array}$ & $\begin{array}{r}-1.265 \\
(0.932)\end{array}$ & $\begin{array}{r}-0.902 \\
(0.987)\end{array}$ & $\begin{array}{r}-0.565 \\
(0.814)\end{array}$ & $\begin{array}{r}-0.567 \\
(0.816)\end{array}$ & $\begin{array}{r}-0.375 \\
(0.797)\end{array}$ \\
\hline $\begin{array}{l}\text { Increase in state spending on education } \\
\text { In percent of NSDP, over the previous period averag }\end{array}$ & & $\begin{array}{r}0.508 \\
(1.918)\end{array}$ & & & $\begin{array}{r}-3.139 \\
(2.312)\end{array}$ & & & $\begin{array}{r}1.372 \\
(1.482)\end{array}$ & \\
\hline $\begin{array}{l}\text { Increase in literacy rate } \\
\text { In percent per year }\end{array}$ & & & $\begin{array}{l}3.378 * * * \\
(0.943)\end{array}$ & & & $\begin{array}{r}1.041 \\
(1.148)\end{array}$ & & & $\begin{array}{c}1.507 * \\
(0.803)\end{array}$ \\
\hline $\begin{array}{l}\text { Literacy rate, end of previous period }{ }^{1} \\
\quad \text { In percent of state's total population }\end{array}$ & & & $\begin{array}{l}0.231^{* * *} \\
(0.099)\end{array}$ & & & $\begin{array}{c}0.312 * \\
(0.179)\end{array}$ & & & $\begin{array}{r}0.006 \\
(0.083)\end{array}$ \\
\hline Number of observations & 48 & 48 & 48 & 48 & 48 & 48 & 48 & 48 & 48 \\
\hline $\mathrm{R}^{2}$ & 0.76 & 0.76 & 0.79 & 0.34 & 0.38 & 0.45 & 0.80 & 0.80 & 0.93 \\
\hline
\end{tabular}

Source: IMF staff estimates.

1/ Average expenditure and redistribution components are measured as percentage point contributions to percentage decline in the poverty headcount. Note: Period dummies included, not reported in the table. Robust standard errors in parentheses.

Note: ${ }^{* * *},{ }^{* *},{ }^{*}$ indicates 1,5 , and 10 percent statistical significance, respectively. 
The results for education variables are generally similar to the inclusive growth regressions, suggesting that higher initial literacy and greater literacy are associated with greater poverty reduction. At the same time, the interesting result is how greater literacy transmits through growth and the redistribution channels of poverty reduction. It appears that more education is significant only in the redistribution channel regressions, while the initial level of education is significant in the growth channel regression. This suggests that the less well-off households are benefiting from more education as reflected in the shifting shape of welfare distribution. Indeed, the literacy data indicates that the lower deciles of expenditure distribution have experienced relatively large gains in literacy attainment rates across the country.

Next we turn to the analysis of inclusive growth for rural and urban households separately, where we try to account for both differences in expenditure growth and poverty reduction outcomes, as well as for differences in explanatory variables.

Tables 7 and 8 present the results for rural households. Overall, the inclusive growth regression results are similar to the regressions on the combined rural and urban household data, which is not surprising given the predominance of the rural population. However, some differences are worth pointing out.

First, the role of credit is manifested primarily through the redistribution channel. With financial deepening, relatively poorer households gain access to bank credit, boosting their consumption. The link between credit and the growth of average expenditure is not as statistically strong, which perhaps reflects that credit is still likely to be more effective for urban households and perhaps, therefore, a reason for the rising rural-urban divide.

Second, the role of social spending, both the magnitude and levels of statistical significance of coefficients, is very similar for rural and urban regressions. It matters primarily through the average rate of welfare growth ${ }^{19}$. Quantitatively similar results are also evident for inflation, although its negative impact is not clear through the equity component. As mentioned above, this likely reflects a problem associated with using a uniform state-specific rural inflation aggregate, which fails to pick up the differential impact of inflation on real expenditure of different welfare deciles for rural households.

The second and third specifications for inclusive growth as well as its components presented in Table 7 examine their connection with education-related variables. We find a similar link between growth and states' education spending, which appears to have an impact through the equity component. With respect to literacy, the results are similar to the regression based on states' combined urban and rural population.

\footnotetext{
${ }^{19}$ Tapsoba (2013) also finds that fiscal consolidation strategies for India in which deficit reduction is accompanied by greater investment and social spending lead to better growth and welfare outcomes.
} 
The regressions on the Datt-Ravallion decomposition (Table 8) suggest that although financial deepening helps improve welfare distribution, the impact on poverty reduction is not statistically significant. Furthermore, the regression analysis of the redistribution component of poverty reduction does not reveal statistically significant coefficients in comparison to the regression of the growth inclusiveness component. This is likely a reflection of a more thorough account of shifts in households' consumption distribution and welfare in the inclusive growth measure, especially among poor households. This suggests that the inclusiveness measure may be more appropriate for capturing relationships between socio-economic progress and improvement in welfare of households below the poverty line.

\begin{tabular}{|c|c|c|c|c|c|c|c|c|c|}
\hline \multirow[t]{2}{*}{ Dependent Variable: } & \multicolumn{3}{|c|}{$\begin{array}{l}\text { Inclusive growth } \\
\text { In percent per year }\end{array}$} & \multicolumn{3}{|c|}{$\begin{array}{l}\text { Average expenditure component } \\
\text { In percent per year }\end{array}$} & \multicolumn{3}{|c|}{$\begin{array}{l}\text { Inclusiveness component } \\
\text { In percent per year }\end{array}$} \\
\hline & (1) & $(2)$ & (3) & (4) & $(5)$ & (6) & (7) & (8) & (9) \\
\hline $\begin{array}{l}\text { Credit-to-GDP ratio } \\
\quad \text { In percent, period average }\end{array}$ & $\begin{array}{r}0.015 \\
(0.010)\end{array}$ & $\begin{array}{r}0.015 \\
(0.010)\end{array}$ & $\begin{array}{r}0.016 \\
(0.010)\end{array}$ & $\begin{array}{r}0.004 \\
(0.007)\end{array}$ & $\begin{array}{r}0.004 \\
(0.007)\end{array}$ & $\begin{array}{r}0.004 \\
(0.007)\end{array}$ & $\begin{array}{l}0.011^{* *} \\
(0.005)\end{array}$ & $\begin{array}{l}0.011^{* *} \\
(0.005)\end{array}$ & $\begin{array}{l}0.012 \text { ** } \\
(0.005)\end{array}$ \\
\hline $\begin{array}{l}\text { Real per capita state social sector expenditure } \\
\text { In percent of poverty line, average per year }\end{array}$ & $\begin{array}{l}0.027^{* *} \\
(0.013)\end{array}$ & $\begin{array}{l}0.028 \text { ** } \\
(0.013)\end{array}$ & $\begin{array}{r}0.019 \\
(0.013)\end{array}$ & $\begin{array}{l}0.030^{* * *} \\
(0.010)\end{array}$ & $\begin{array}{l}0.027 \text { ** } \\
(0.006)\end{array}$ & $\begin{array}{r}0.014 \\
(0.011)\end{array}$ & $\begin{array}{r}-0.003 \\
(0.008)\end{array}$ & $\begin{array}{r}0.002 \\
(0.008)\end{array}$ & $\begin{array}{r}0.005 \\
(0.008)\end{array}$ \\
\hline $\begin{array}{l}\text { Inflation rate }{ }^{1} \\
\quad \text { In percent per year, period average }\end{array}$ & $\begin{array}{l}-0.697^{* * *} \\
(0.175)\end{array}$ & $\begin{array}{l}-0.699 * * * \\
(0.179)\end{array}$ & $\begin{array}{l}-0.542 \text { ** } \\
(0.215)\end{array}$ & $\begin{array}{l}-0.706 * * * \\
(0.168)\end{array}$ & $\begin{array}{l}-0.702 * * * \\
(0.165)\end{array}$ & $\begin{array}{l}-0.727^{* * *} \\
(0.171)\end{array}$ & $\begin{array}{r}0.012 \\
(0.102)\end{array}$ & $\begin{array}{r}0.007 \\
(0.102)\end{array}$ & $\begin{array}{r}0.004 \\
(0.101)\end{array}$ \\
\hline $\begin{array}{l}\text { Increase in state spending on education } \\
\text { In percent of NSDP, over previous period's average }\end{array}$ & & $\begin{array}{r}0.155 \\
(0.457)\end{array}$ & & & $\begin{array}{r}-0.306 \\
(0.388)\end{array}$ & & & $\begin{array}{l}0.450 * \\
(0.257)\end{array}$ & \\
\hline $\begin{array}{l}\text { Increase in literacy rate } \\
\text { In percent per year }\end{array}$ & & & $\begin{array}{l}0.766^{* *} \\
(0.379)\end{array}$ & & & $\begin{array}{r}0.498 \\
(0.305)\end{array}$ & & & $\begin{array}{l}0.273 * \\
(0.145)\end{array}$ \\
\hline $\begin{array}{l}\text { Literacy rate, end of previous period } \\
\text { In percent of state's rural population }\end{array}$ & & & $\begin{array}{l}0.070 * \\
(0.038)\end{array}$ & & & $\begin{array}{l}0.075^{* *} \\
(0.032)\end{array}$ & & & $\begin{array}{r}-0.004 \\
(0.014)\end{array}$ \\
\hline Number of observations & 48 & 48 & 48 & 48 & 48 & 48 & 48 & 48 & 48 \\
\hline $\mathrm{R}^{2}$ & 0.36 & 0.37 & 0.48 & 0.30 & 0.31 & 0.43 & 0.43 & 0.47 & 0.54 \\
\hline
\end{tabular}

Source: IMF staff estimates.

Note: Period dummies included, not reported in the table. Robust standard errors in parentheses.

Note: ${ }^{* \star *},{ }^{* \star},{ }^{*}$ indicates 1,5 , and 10 percent statistical significance, respectively.

${ }^{1}$ Corresponds to state-level rural or urban population specific indicator.

Table 8. Regression Analysis of Poverty Reduction (Datt-Ravallion Decomposition): Rural Households 1/

\begin{tabular}{|c|c|c|c|c|c|c|c|c|c|}
\hline \multirow[t]{2}{*}{ Dependent Variable: } & \multicolumn{3}{|c|}{$\begin{array}{l}\text { Poverty Reduction } \\
\text { In percent per year }\end{array}$} & \multicolumn{3}{|c|}{$\begin{array}{l}\text { Average expenditure component } \\
\text { In percent per year }\end{array}$} & \multicolumn{3}{|c|}{$\begin{array}{l}\text { Redistribution component } \\
\text { In percent per year }\end{array}$} \\
\hline & (1) & (2) & (3) & (4) & (5) & (6) & (7) & (8) & (9) \\
\hline $\begin{array}{l}\text { Credit-to-GDP ratio } \\
\text { In percent, period average }\end{array}$ & $\begin{array}{r}0.035 \\
(0.047)\end{array}$ & $\begin{array}{r}0.035 \\
(0.048)\end{array}$ & $\begin{array}{r}0.041 \\
(0.050)\end{array}$ & $\begin{array}{r}-0.054 \\
(0.042)\end{array}$ & $\begin{array}{r}-0.054 \\
(0.042)\end{array}$ & $\begin{array}{r}-0.060 \\
(0.045)\end{array}$ & $\begin{array}{r}0.040 \\
(0.029)\end{array}$ & $\begin{array}{r}0.039 \\
(0.031)\end{array}$ & $\begin{array}{r}0.047 \\
(0.031)\end{array}$ \\
\hline $\begin{array}{l}\text { Real per capita state social sector expenditure } \\
\text { In percent of poverty line, average per year }\end{array}$ & $\begin{array}{r}0.069 \\
(0.107)\end{array}$ & $\begin{array}{r}0.079 \\
(0.111)\end{array}$ & $\begin{array}{r}0.047 \\
(0.111)\end{array}$ & $\begin{array}{l}0.257^{* * *} \\
(0.096)\end{array}$ & $\begin{array}{l}0.258^{* *} \\
(0.101)\end{array}$ & $\begin{array}{l}0.181 * \\
(0.098)\end{array}$ & $\begin{array}{r}-0.117 \\
(0.070)\end{array}$ & $\begin{array}{r}-0.099 \\
(0.072)\end{array}$ & $\begin{array}{r}-0.081 \\
(0.078)\end{array}$ \\
\hline $\begin{array}{l}\text { Inflation rate }{ }^{1} \\
\quad \text { In percent per year, period average }\end{array}$ & $\begin{array}{l}-2.674^{* * *} \\
(0.989)\end{array}$ & $\begin{array}{l}-2.684^{\star \star *} \\
(1.016)\end{array}$ & $\begin{array}{l}-1.953 * \\
(1.183)\end{array}$ & $\begin{array}{l}-1.685^{\star *} \\
(0.812)\end{array}$ & $\begin{array}{l}-1.687^{\star *} \\
(0.817)\end{array}$ & $\begin{array}{l}-1.329 * \\
(0.803)\end{array}$ & $\begin{array}{r}-0.182 \\
(0.883)\end{array}$ & $\begin{array}{l}-0.201 \\
(0.901)\end{array}$ & $\begin{array}{l}-0.006 \\
(0.952)\end{array}$ \\
\hline $\begin{array}{l}\text { Increase in state spending on education } \\
\text { In percent of NSDP, over previous period's average }\end{array}$ & & $\begin{array}{r}0.939 \\
(2.557)\end{array}$ & & & $\begin{array}{r}0.076 \\
(1.492)\end{array}$ & & & $\begin{array}{r}1.678 \\
(2.015)\end{array}$ & \\
\hline $\begin{array}{l}\text { Increase in literacy rate }{ }^{1} \\
\text { In percent per year }\end{array}$ & & & $\begin{array}{l}3.790 * * \\
(1.562)\end{array}$ & & & $\begin{array}{r}0.445 \\
(1.069)\end{array}$ & & & $\begin{array}{r}1.747 \\
(1.416)\end{array}$ \\
\hline $\begin{array}{l}\text { Literacy rate, end of previous period }{ }^{1} \\
\qquad \text { In percent of state's rural population }\end{array}$ & & & $\begin{array}{l}0.311^{* *} \\
(0.153)\end{array}$ & & & $\begin{array}{l}0.243^{* *} \\
(0.110)\end{array}$ & & & $\begin{array}{r}0.019 \\
(0.154)\end{array}$ \\
\hline Number of observations & 48 & 48 & 48 & 48 & 48 & 48 & 48 & 48 & 48 \\
\hline$R^{2}$ & 0.78 & 0.78 & 0.80 & 0.35 & 0.36 & 0.41 & 0.79 & 0.79 & 0.80 \\
\hline
\end{tabular}

Source: IMF staff estimates.

1/ Average expenditure and redistribution components are measured as percentage point contributions to percentage decline in poverty headcount.

Note: Period dummies included, not reported in the table. Robust standard errors in parentheses.

Note: ${ }^{* * *},{ }^{* *},{ }^{*}$ indicates 1,5 , and 10 percent statistical significance, respectively.

${ }^{1}$ Corresponds to state-level rural or urban population specific indicator. 
Tables 9 and 10 present the results for urban households. As with the rural regressions, we find that the states' credit-to-GDP ratio is positively associated with our measure of inclusive growth. However, its contribution through the equity component does not appear as statistically significant as for rural household regressions. As well, we find a significant positive association between inclusive growth and both higher initial literacy and more literacy. Similar to rural households, higher initial literacy appears to be linked to inclusiveness through the growth of average household expenditure, suggesting that higher literacy across a state's population could provide for a base for broader growth. The economic impact of increases in literacy is also apparent through both average growth rates and through the distribution. Finally, we do not find a strong link between social spending and growth inclusiveness or urban poverty reduction, and also find a negative but statistically insignificant relationship between inclusive growth and urban inflation.

Table 9. Regression Analysis of Growth Inclusiveness: Urban Households

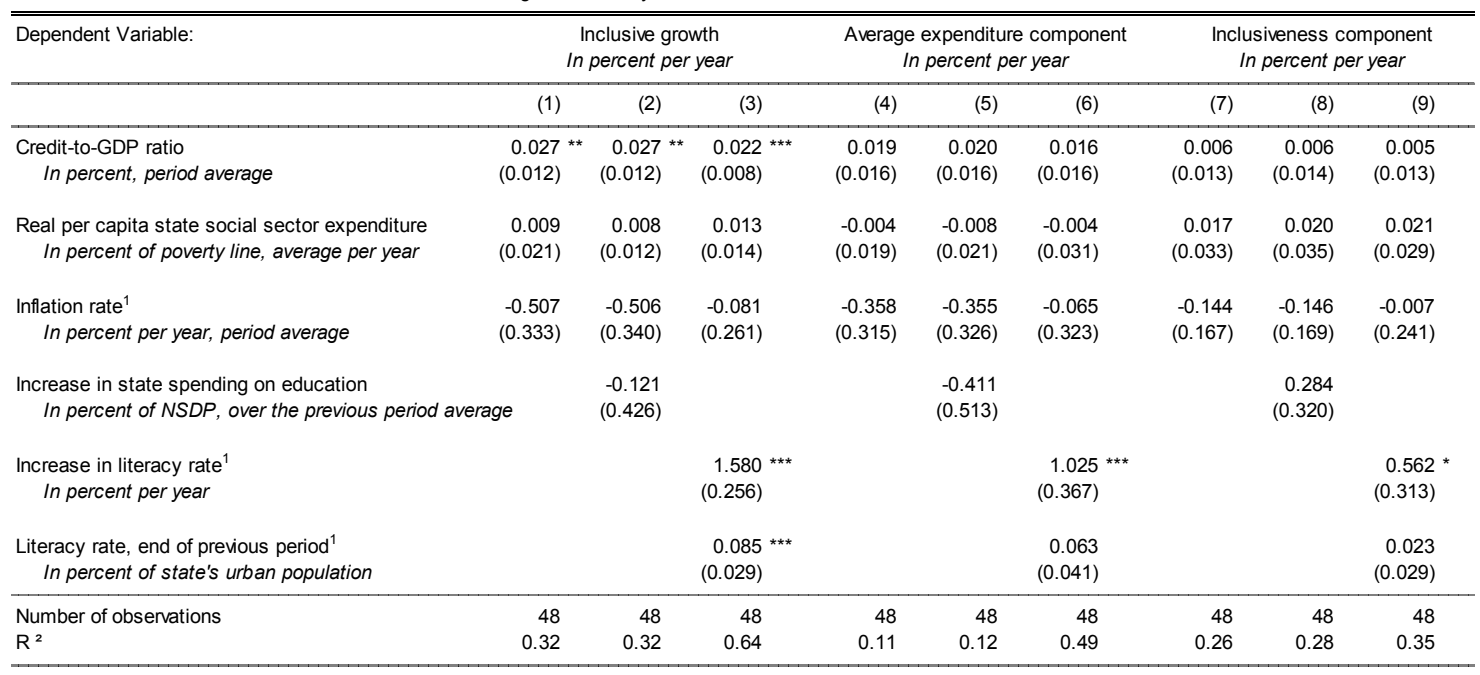

Source: IMF staff estimates.

Note: Period dummies included, not reported in the table. Robust standard errors in parentheses.

Note: ${ }^{* * *}, * *,{ }^{*}$ indicates 1,5 , and 10 percent statistical significance, respectively.

${ }^{1}$ Corresponds to state-level rural or urban population specific indicator.

Table 10. Regression Analysis of Poverty Reduction (Datt-Ravallion Decomposition): Urban Households 1/

\begin{tabular}{|c|c|c|c|c|c|c|c|c|c|}
\hline \multirow[t]{2}{*}{ Dependent Variable: } & \multicolumn{3}{|c|}{$\begin{array}{l}\text { Poverty Reduction } \\
\text { In percent per year }\end{array}$} & \multicolumn{3}{|c|}{$\begin{array}{l}\text { Average expenditure component } \\
\text { In percent per year }\end{array}$} & \multicolumn{3}{|c|}{$\begin{array}{l}\text { Redistribution component } \\
\text { In percent per year }\end{array}$} \\
\hline & (1) & (2) & (3) & (4) & (5) & (6) & (7) & (8) & (9) \\
\hline $\begin{array}{l}\text { Credit-to-GDP ratio } \\
\quad \text { In percent, period average }\end{array}$ & $\begin{array}{r}0.108 \\
(0.066)\end{array}$ & $\begin{array}{r}0.108 \\
(0.067)\end{array}$ & $\begin{array}{r}0.103 \\
(0.064)\end{array}$ & $\begin{array}{r}0.055 \\
(0.050)\end{array}$ & $\begin{array}{r}0.060 \\
(0.060)\end{array}$ & $\begin{array}{r}0.063 \\
(0.051)\end{array}$ & $\begin{array}{r}0.061 \\
(0.082)\end{array}$ & $\begin{array}{r}0.060 \\
(0.084)\end{array}$ & $\begin{array}{r}0.061 \\
(0.085)\end{array}$ \\
\hline $\begin{array}{l}\text { Real per capita state social sector expenditure } \\
\text { In percent of poverty line, average per year }\end{array}$ & $\begin{array}{r}-0.059 \\
(0.180)\end{array}$ & $\begin{array}{r}-0.058 \\
(0.186)\end{array}$ & $\begin{array}{r}-0.120 \\
(0.191)\end{array}$ & $\begin{array}{r}-0.009 \\
(0.086)\end{array}$ & $\begin{array}{r}-0.044 \\
(0.085)\end{array}$ & $\begin{array}{r}-0.103 \\
(0.108)\end{array}$ & $\begin{array}{r}-0.029 \\
(0.212)\end{array}$ & $\begin{array}{r}-0.021 \\
(0.221)\end{array}$ & $\begin{array}{r}-0.066 \\
(0.236)\end{array}$ \\
\hline $\begin{array}{l}\text { Inflation rate }{ }^{1} \\
\qquad \text { In percent per year, period average }\end{array}$ & $\begin{array}{r}1.758 \\
(1.574)\end{array}$ & $\begin{array}{r}1.757 \\
(1.600)\end{array}$ & $\begin{array}{r}2.320 \\
(1.883)\end{array}$ & $\begin{array}{r}-0.661 \\
(1.110)\end{array}$ & $\begin{array}{r}-0.530 \\
(1.115)\end{array}$ & $\begin{array}{r}0.510 \\
(1.149)\end{array}$ & $\begin{array}{r}2.641 \\
(1.609)\end{array}$ & $\begin{array}{r}2.634 \\
(1.656)\end{array}$ & $\begin{array}{r}2.635 \\
(1.952)\end{array}$ \\
\hline $\begin{array}{l}\text { Increase in state spending on education } \\
\text { In percent of NSDP, over the previous period average }\end{array}$ & & $\begin{array}{r}0.093 \\
(2.254)\end{array}$ & & & $\begin{array}{r}-2.880 \\
(1.846)\end{array}$ & & & $\begin{array}{r}0.780 \\
(2.234)\end{array}$ & \\
\hline $\begin{array}{l}\text { Increase in literacy rate }{ }^{1} \\
\text { In percent per year }\end{array}$ & & & $\begin{array}{r}0.578 \\
(2.717)\end{array}$ & & & $\begin{array}{l}3.707^{* * *} \\
(1.158)\end{array}$ & & & $\begin{array}{r}-0.846 \\
(2.802)\end{array}$ \\
\hline $\begin{array}{l}\text { Literacy rate, end of previous period }{ }^{1} \\
\text { In percent of state's urban population }\end{array}$ & & & $\begin{array}{r}0.232 \\
(0.259)\end{array}$ & & & $\begin{array}{l}0.322 \text { ** } \\
(0.160)\end{array}$ & & & $\begin{array}{r}0.065 \\
(0.255)\end{array}$ \\
\hline Number of observations & 48 & 48 & 48 & 48 & 48 & 48 & 48 & 48 & 48 \\
\hline$R^{2}$ & 0.43 & 0.32 & 0.44 & 0.07 & 0.13 & 0.22 & 0.35 & 0.35 & 0.46 \\
\hline
\end{tabular}

Source: IMF staff estimates.

1/ Average expenditure and redistribution components are measured as percentage point contributions to percentage decline in poverty headcount.

Note: Period dummies included, not reported in the table. Robust standard errors in parentheses.

Note: ${ }^{* * *}, * *,{ }^{*}$ indicates 1,5 , and 10 percent statistical significance, respectively.

${ }^{1}$ Corresponds to state-level rural or urban population specific indicator. 


\section{Growth Slowdown And Poverty}

The Indian Government's Twelfth Five-Year Plan document has acknowledged that while the objective of development is broad-based improvement in economic and social conditions, rapid growth of GDP is an essential requirement for achieving this objective. First, rapid GDP growth produces a larger expansion in total income and production which, if the growth process is sufficiently inclusive, will directly raise the living standards of a large section of the population by providing them with employment and other income enhancing activities. The second reason why rapid growth is important for inclusiveness is that it generates higher revenues, which help to finance critical programs for inclusiveness.

The current slowdown in growth, if protracted, would severely hamper poverty reduction. Using the long-term estimate of the growth elasticity of poverty reduction ${ }^{20}$ of 0.5 (Table 11), the current subdued economic outlook implies a 30 percent lower reduction in the poverty headcount ratio by 2015 compared with a scenario in which growth would have remained at the

\begin{tabular}{lccc}
\multicolumn{4}{c}{$\begin{array}{c}\text { Table 11. India: Growth and Poverty Reduction } \\
\text { (Annual percent change, unless indicated otherwise) }\end{array}$} \\
\hline \hline & 1993/94-2004/05 & 2004/05-2009/10 & 1993/94-2009/10 \\
\hline Real GDP per capita & 4.90 & 6.51 & 5.09 \\
Headcount index (\$1.25) & -1.69 & -4.74 & -2.55 \\
National poverty line & -1.95 & -4.34 & -2.58 \\
Elasticity of poverty reduction to GDP growth & & \\
Headcount index (\$1.25) & -0.35 & -0.73 & -0.50 \\
National poverty line & -0.40 & -0.67 & -0.51 \\
\hline Source: IMF staff estimates. & &
\end{tabular}
2004-09 average. Indeed, the average growth rate of just 51/2 percent during 2010/112012/13 and the subdued near-term growth outlook provide for a more challenging poverty reduction platform compared to a record-high five-year average growth rate of $8 \frac{1}{2}$ percent achieved during 2004/05-2009/10.

\section{Conclusions}

Robust economic growth is imperative for strong government revenue growth and, as a result, for ensuring adequate fiscal space for developmental spending, in particular social sector spending. As demonstrated in our empirical analysis, such government expenditures are closely linked to inclusive growth and poverty reduction. Specifically, our econometric results suggest that boosting social sector spending by about 1 percent of GDP is associated with about 0.5 percentage point decline in the poverty rate ${ }^{21}$. Therefore, undertaking revenueboosting reforms to create fiscal space for higher public investments and social expenditures while supporting fiscal consolidation would help to make progress in reducing poverty.

A better-educated labor force provides a foundation for robust and inclusive growth, as well as for continued poverty reduction. Our analysis shows that states in India that boosted

${ }^{20}$ Calculated as a proportional change in poverty per unit growth in GDP per capita.

${ }^{21}$ Based on the social spending coefficient estimate from column (4) in Table 6 and assuming unchanged welfare distribution. 
spending on education and those that achieved progress on fundamental educational attainment had better inclusive growth outcomes. Furthermore, we also find a positive association between a state's initial literacy rates and inclusive growth outcomes. Therefore, raising the quality of the labor force through better access to education can help unlock a virtuous cycle of higher potential growth. Needless to say, the presence of appropriate labor market policies and continued structural reforms are critical to enable education to enhance and broaden economic growth.

Sustaining robust and inclusive growth will require maintaining macrofinancial stability, with particular attention to inflation risks. As our analysis indicates, lower inflation goes hand-in-hand with more inclusive growth and better poverty reduction outcomes. Also, states with relatively deeper bank credit achieved better growth, through boosting inclusiveness in particular. Safeguarding financial stability is therefore critical for ensuring continued financial deepening, increasing access to finance, and broadening growth. Finally, anchoring the government's socioeconomic development agenda to a sustainable financial position lays a cornerstone for broad macroeconomic and financial stability. 


\section{APPENDIX I: DATA DESCRIPTION}

State Domestic Product. We have used estimates of SDP (income originating within the state) provided by the Central Statistical Organization of India. Specifically, per capita net state domestic income at constant prices, therefore, is treated as the variable in our forthcoming analysis. So, in our analysis of the disparity of states' income, we consider per capita net state domestic product (henceforth used as PCNSDP) instead of net state domestic product where domestic state product represents income generated within a state's boundaries.

Real per capita state social sector expenditure. These figures are taken from the IndiaStat database based on data provided by the Reserve Bank of India (ON56). Nominal state-wise per capita social sector expenditures are deflated by state-level poverty lines to construct measures of real per capita social expenditure. For rural- and urban-specific variables, state level expenditures are deflated by rural- or urban-specific state poverty lines. Observations correspond to period averages.

Inflation rate. Source is CEIC. Rural and urban state household measures correspond to state-level CPI for industrial worker (urban) and agricultural laborer (rural). State-level aggregate inflation measure is constructed using a population-weighted measure of urban and rural inflation rates. Observations correspond to period average annual inflation rates.

State spending on education. Defined as state-wise public expenditure on education as a percentage of NSDP. The source for data before 2000 is Chakrabarti and Joglekar (2006); data from later years comes from the Reserve Bank of India's publication "State Finances: A Study of Budgets of 2010-11".

Literacy rate. State-wise literacy rates are calculated from NSSO household surveys.

Bank credit by state. This is commercial bank credit to the private sector, which is taken from the Reserve Bank of India's Statistical Tables Relating to Banks in India. 


\section{REFERENCES}

Ali, Ifzal and Hyun Hwa Son, 2007, "Measuring Inclusive Growth," Asian Development Review, Vol. 24, No. 1, pp. 11-31.

Anand, Rahul, Saurabh Mishra and Shanaka J. Peiris, 2013, "Inclusive Growth: Measurement and Determinants," IMF Working Paper 13/135 (Washington: International Monetary Fund).

Banerjee, Abhijit and Thomas Piketty, 2005, “Top Indian Incomes, 1922-2000." World Bank Economic Review, Vol. 19, No. 1, pp. 1-20.

Barro, Robert J., 1991, "Economic Growth in a Cross Section of Countries," The Quarterly Journal of Economics, Vol. 106, No. 2, pp. 407-443.

Benhabib, Jess and Mark M. Spiegel, 1994, "The Role of Human Capital in Economic Development: Evidence from Aggregate Cross-Country Data," Journal of Monetary Economics, Elsevier, Vol. 34, No. 2, pp. 143-173.

Berg, Andrew and Jonathan D. Ostry, 2011, "Inequality and Unsustainable Growth: Two Sides of the Same Coin?” IMF Staff Discussion Note 11/08 (Washington: International Monetary Fund).

Bhagwati, Jagdish and Arvind Panagariya, 2013, Why Growth Matters: How Economic Growth in India Reduced Poverty and the Lessons for Other Developing Countries, New York: Public Affairs.

Bhagwati, Jagdish and Arvind Panagariya, 2012, India's Reforms: How they Produced Inclusive Growth, OUP Catalogue, Oxford University Press.

Bhalla, Surjit, 2003, "Not as Poor, Nor as Unequal, as You Think-Poverty, Inequality and Growth in India, 1950-2000," Available via the Internet: http://www.oxusresearch.com/economic.asp

Chakrabarti, Anindita and Rama Joglekar, 2006, "Determinants of Expenditure on Education: an Empirical Analysis Using State Level Data From India, Economic and Political Weekly, Vol. XLI , April 15-21, pp. 1465-1472.

Deaton, Angus and Valerie Kozel, 2005, "Data and Dogma: The Great Indian Poverty Debate," World Bank Research Observer, Vol. 20, pp. 177-199.

International Monetary Fund, 2007, “Globalization and Inequality,” World Economic Outlook, Chapter 4, October (Washington: International Monetary Fund).

Kraay, Aart, 2004, "When is Growth Pro-Poor? Cross-Country Evidence," IMF Working Paper 04/47 (Washington: International Monetary Fund). 
Planning Commission of India, 2013, "Press Note on Poverty Estimates, 2011-12," July 2013, Government of India.

Pritchett, Lant, 2001, "Where Has All the Education Gone?" World Bank Economic Review, Vol. 15, No. 3, pp. 367-391.

Purfield, Catriona, 2006, "Mind the Gap - Is Economic Growth in India Leaving Some States Behind?” IMF Working Paper 06/103 (Washington: International Monetary Fund).

Ravallion, Martin, and Gaurav Datt, 1992, "Growth and Redistribution Components of Changes in Poverty Measures: A Decomposition with Applications to Brazil and India in the 1980s." Journal of Development Economics, Vol. 38, pp. 275-295.

—, 1996. "Why Have Some Indian States Done Better than Others at Reducing Rural Poverty?”, Policy Research Working Paper Series 1594, The World Bank.

—, 2002a, "Why has Economic Growth Been More Pro-Poor in Some States of India Than Others?" Journal of Development Economics, Vol. 68, pp. 381-400.

—, 2002b, "Is India's Economic Growth Leaving the Poor Behind?" Journal of Economic Perspectives, Vol. 16, No. 3, pp. 89-108.

Tapsoba, Sampawende J.-A., 2013, “Options and Strategies for Fiscal Consolidation in India,” IMF Working Paper 13/127 (Washington: International Monetary Fund).

Topalova, Petia, 2008, “India: Is the Rising Tide Lifting All Boats?” IMF Working Paper 08/54 (Washington: International Monetary Fund). 